\title{
Learning the Vector Coding of Egocentric Boundary Cells from Visual Data
}

1 Author Names and Affiliations: Yanbo Lian ${ }^{1 \ddagger *}$, Simon Williams ${ }^{2 \ddagger *}$, Andrew S. Alexander ${ }^{3}$, Michael E. 2 Hasselmo $^{3}$, Anthony N. Burkitt ${ }^{1}$

$3^{1}$ Department of Biomedical Engineering, The University of Melbourne, Melbourne, VIC 3010, Australia

42 Department of Electrical and Electronic Engineering, University of Melbourne, Melbourne, VIC 3010, 5 Australia

$6 \quad 3$ Center for Systems Neuroscience, Department of Psychological and Brain Sciences, Boston University, 7610 Commonwealth Ave., Boston, MA 02215, USA

$8 \quad \$$ These authors contributed equally to this work.

9 *Correspondence: yanbo.lian@unimelb.edu.au, simon.williams@unimelb.edu.au

Acknowledgements: This work received funding from the Australian Government, via grant AUSMURIB000001 associated with ONR MURI grant N00014-19-1-2571. This research was also supported by NIH NINDS F32 NS101836-01, NIMH R01 MH120073; Office of Naval Research MURI grant N0001416-1-2832; Office of Naval Research MURI N00014-19-1-2571; and Office of Naval Research DURIP N00014-17-1-2304.

Conflict of interest statement: The authors declare no competing financial interests. 


\section{Abstract}

The use of spatial maps to navigate through the world requires a complex ongoing transformation of egocentric views of the environment into position within the allocentric map. Recent research has discovered neurons in retrosplenial cortex and other structures that could mediate the transformation from egocentric views to allocentric views. These egocentric boundary cells (EBCs) respond to the egocentric direction and distance of barriers relative to an animals point of view. This egocentric coding based on the visual features of barriers would seem to require complex dynamics of cortical interactions. However, computational models presented here show that egocentric boundary cells can be generated with a remarkably simple synaptic learning rule that forms a sparse representation of visual input as an animal explores the environment. Simulation of this simple sparse synaptic modification generates a population of egocentric boundary cells with distributions of direction and distance coding that strikingly resemble those observed within the retrosplenial cortex. This provides a framework for understanding the properties of neuronal populations in the retrosplenial cortex that may be essential for interfacing egocentric sensory information with allocentric spatial maps of the world formed by neurons in downstream areas including the grid cells in entorhinal cortex and place cells in the hippocampus.

\section{Introduction}

Animals can perform extremely complex spatial navigation tasks, but how the brain implements a navigational system to accomplish this remains largely unknown. In the past few decades, many functional cells that play an important role in spatial cognition have been discovered, including place cells (O'Keefe and Dostrovsky, 1971; O'Keefe, 1976), head direction cells (Taube et al., 1990a,b), grid cells (Hafting et al., 2005; Stensola et al., 2012), boundary cells (Solstad et al., 2008; Lever et al., 2009), and speed cells (Kropff et al., 2015; Hinman et al., 2016). All of these cells have been investigated in the allocentric reference frame that is viewpoint-invariant.

However, animals experience and learn about environmental features through exploration using sensory input that is in their egocentric reference frame. Recently, some egocentric spatial representations have been found in multiple brain areas such as lateral entorhinal cortex (Wang et al., 2018), postrhinal cortices 
(Gofman et al., 2019; LaChance et al., 2019), dorsal striatum (Hinman et al., 2019), and the retrosplenial cortex (RSC) (Alexander et al., 2020; Wang et al., 2018). In the studies by Hinman et al. (2019) and Alexander et al. (2020), a very interesting type of spatial cell, the egocentric boundary cell, was discovered. Similar to allocentric boundary cells (Solstad et al., 2008; Lever et al., 2009), egocentric boundary cells (EBCs) possess vectorial receptive fields sensitive to the bearing and distance of nearby walls or boundaries, but in the egocentric reference frame. For example, an EBC of a rat that responds whenever there is a wall at at particular distance on the left of the rat means that the response of the EBC not only depends on the location of the animal but also its running direction or head direction, i.e., the cell is tuned to a wall in the animal-centered reference frame.

Alexander et al. (2020) identified three categories of EBCs in the rat RSC: proximal EBCs whose egocentric receptive field boundary is close to the animal, distal EBCs whose egocentric receptive field boundary is further away from the animal, and inverse EBCs that respond everywhere in the environment except when the animal is close to the boundary. Some examples of proximal, distal and inverse EBCs are shown in Figure 1. Furthermore, EBCs in this area display a considerable diversity in vector coding; namely the EBCs respond to egocentric boundaries at various orientations and distances. Somewhat surprisingly, there are many EBCs tuned to a wall that is behind the animal (see the top plot of Figure 1B for an example).

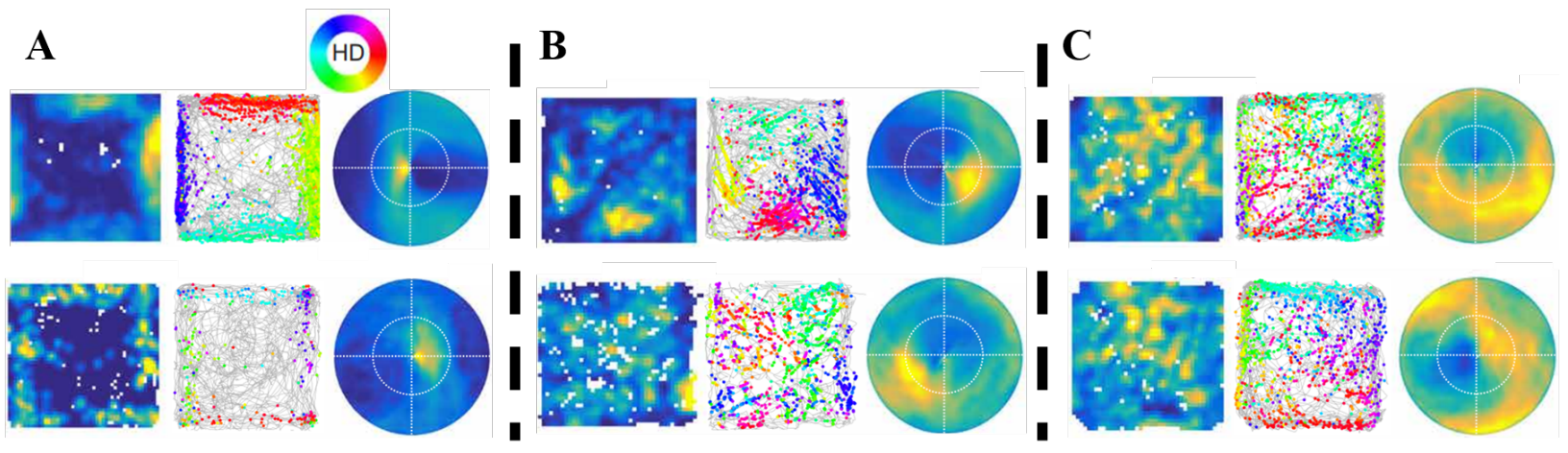

Figure 1: Six example EBCs from Alexander et al. (2020). The plots in the left column are the spatial rate maps, the middle column plots are trajectory plots showing firing locations and head directions (according to the circular color legend shown above (A)), and the right column plots are the receptive fields of the respective EBCs (front direction corresponds to top of page). (A) Proximal EBCs whose receptive field is a wall close to the animal. (B) Distal EBCs whose receptive field is a wall further from the animal. (C) Inverse EBCs that fire everywhere except when there is wall near the animal. 
Though there is increasing experimental evidence that suggests the importance of egocentric spatial cells, there have been few studies explaining how egocentric boundary cells are formed and whether they emerge from neural plasticity.

In this study, we show how EBCs can be generated through a learning process based upon sparse coding that uses visual information as the input. Furthermore, the learnt EBCs show a diversity of types, namely proximal, distal and inverse, and they fire for boundaries at different orientations and distances, similar to that observed in experimental studies of the vector coding for EBCs (Alexander et al., 2020). As Bicanski and Burgess (2020) pointed out in a recent review, the fact that some EBCs respond for boundaries behind the animal suggests that these cells do not solely rely on sensory input and appear to incorporate some mnemonic components. However, our model shows that by solely taking visual input, without any mnemonic component, some learnt EBCs respond to boundaries that are behind the animal and out of view. These boundaries can, nevertheless, be inferred from distal visual cues, suggesting that the competition introduced by sparse coding drives different model cells to learn responses to boundaries at a wide range of different directions.

\section{Materials and Methods}

\subsection{The simulated environment, trajectory and visual input}

\subsubsection{Environment}

The simulated environment is programmed to match the experimental setup of Alexander et al. (2020) as closely as possible. It consists of a virtual walled arena $125 \mathrm{~cm}$ by $125 \mathrm{~cm}$. One virtual wall is white and the other three are black. The floor is a lighter shade of grey with RGB values $(0.4,0.4,0.4)$.

\subsubsection{Trajectory}

The simulated trajectory is generated randomly using the parameters from Raudies and Hasselmo (2012). The simulated animal starts in the center of the arena facing north with the white wall to the right. This is used as the $0^{\circ}$ bearing direction. The velocity of the animal is sampled from a Rayleigh distribution with mean $13 \mathrm{~cm} / \mathrm{s}$ while enforcing a minimum speed of $5 \mathrm{~cm} / \mathrm{s}$. 
The direction of motion is modelled by a random walk for the bearing, where the change in bearing at each time step is sampled from a zero mean normal distribution with standard deviation $340^{\circ}$ per second and scaled to the length of the time step.

A complication for the simulation is how to deal with the walls. Following Raudies and Hasselmo (2012), we encode the following. If the simulated animal will approach within $2 \mathrm{~cm}$ of one of the walls on its next step, its velocity is adjusted to halfway between the current speed and the minimum speed $(5 \mathrm{~cm} / \mathrm{s})$. Additionally we change the bearing by turning away from the wall by $90^{\circ}$.

\subsubsection{Visual input}

The simulated environment and trajectory above are realised using the Panda3D game engine (panda3d. org), an open source framework for creating virtual visual environments, usually for games.

The visual input of the simulated animal is modelled using a camera with a $170^{\circ}$ field of horizontal view to mimic the wide visual field of rat and a $110^{\circ}$ field of vertical view. This input is used to generate a grayscale 8 -bit image $170 \times 110$ pixels, which corresponds approximately to the visual acuity of the rat, namely 1 cycle per degree (Prusky et al., 2000). The camera is always facing front, meaning that the head direction is aligned with the movement direction for the simulated rat.

The simulation is run at 30 frames per second until 40000 frames have been collected, which approximately corresponds to a running trajectory over a period of $1300 \mathrm{~s}(21 \mathrm{~min}, 40 \mathrm{~s})$.

\subsection{Model I: Raw visual model based on non-negative matrix factorisation}

In this model the raw visual data is used as the input $X$, which is a $40000 \times 18700$ matrix. This contains the raw visual data $(170 \times 110)$ flattened for each time step. 100 dictionary elements are generated, which we identify with the neuron responses used in Model II.

Non-negative matrix factorisation (NNMF) for the visual data is calculated using the implementation from the SciKit-Learn python package (Pedregosa et al., 2011). The objective function used is

$$
\|X-W H\|_{2}^{2}+\frac{1}{4}\left(\|W\|_{1}+\|H\|_{1}\right)+\frac{1}{8}\left(\|W\|_{2}^{2}+\|H\|_{2}^{2}\right)
$$


where $W$ are the weights and $H$ are the dictionary elements. The correspondence between these structures and those describing the neural model in Section 2.3 are described after Equation 4. Also $\|\cdot\|_{i}$ is the standard $L_{i}$ norm. Training is only performed for a single iteration to simulate the early stages of receptive field generation.

\subsection{Model II: a biological model of the V1-RSC network based on non-negative sparse cod- ing}

\subsubsection{Non-negative sparse coding}

Sparse coding (Olshausen and Field, 1996, 1997) was originally proposed to demonstrate that simple cells in the primary visual cortex (V1) encode visual input using an efficient representation. The essence of sparse coding is the assumption that neurons within a network can represent the sensory input using a linear combination of some relatively small set of basis features (Olshausen and Field, 1997). Along with its variant, non-negative sparse coding (Hoyer, 2003), the principle of sparse coding provides a compelling explanation for neurophysiological findings for many brain areas such as the retina, visual cortex, auditory cortex, olfactory cortex, somatosensory cortex and other areas (see Beyeler et al. (2019) for a review). Recently, sparse coding with non-negative constraint has been shown to provide an account for learning of the spatial and temporal properties of hippocampal place cells within the entorhinal-hippocampal network (Lian and Burkitt, 2021a,b).

\subsubsection{Model structure}

Non-negative sparse coding is used here to learn EBCs in the RSC and the model structure is given in Figure 2. As the virtual animal runs freely in the 2D environment, an image representing what the animal sees is generated at every location. This image is used as the visual stimulus to the virtual animal and undergoes visual processing corresponding to processing in the early visual system and processing in the primary visual cortex (V1) before projecting to the RSC.

Processing in the early visual system describes the visual processing of the retinal ganglion cells (RGCs). In this study, this is done using divisively normalised difference-of-Gaussian filters that mimic the receptive 
fields of RGCs in the early visual system (Tadmor and Tolhurst, 2000; Ratliff et al., 2010). For any input image, the filtered image $I$ at point $(x, y)$ is given by

$$
I(x, y)=\frac{I_{c}(x, y)-I_{s}(x, y)}{I_{d}(x, y)}
$$

where $I_{c}, I_{s}$, and $I_{d}$ are the response of the input image filtered by three unit-normalised Gaussian filters: center filter $\left(G_{c}\right)$, surround filter $\left(G_{s}\right)$, and divisive normalisation filter $\left(G_{d}\right) . G_{c}-G_{s}$ implements the typical difference-of-Gaussian filter that characterises the center-surround receptive field of retinal ganglion cells and $G_{d}$ describes the local adaptation of RGCs (Troy et al., 1993). The receptive field size of RGCs is set to $9 \times 9$. The standard deviations of $G_{c}, G_{s}$ and $G_{d}$ are set to $1,1.5$ and 1.5, respectively (Borghuis et al., 2008). RGCs are located at each pixel point of the input image except these points that are within 4 pixels of the edges of the input image. For a given input image with size $170 \times 110$, the processed image done by the early visual system has size $162 \times 102$.

Next, visual information processed by the early visual system projects to V1 and is further processed by simple cells and complex cells in V1 (Lian et al., 2019, 2021). The receptive field of a simple or complex cell is characterised by a $13 \times 13$ image. Simple cells are described as Gabor filters with orientations spanning from $0^{\circ}$ to $150^{\circ}$ with step size of $30^{\circ}$, spatial frequencies spanning from 0.1 to 0.2 cycles per pixel with step size of 0.025 , and spatial phases of $0^{\circ}, 90^{\circ}, 180^{\circ}$ and $270^{\circ}$. In addition, a complex cell receives input from 4 simple cells that have the same orientation and spatial frequency but different spatial phases (Movshon et al., 1978b,a; Carandini, 2006). Therefore, at each location of a receptive field, there are $6 \times 5 \times 4=120$ simple cells and $6 \times 5=30$ complex cells. As the receptive field only covers a small part of the visual field, the same simple cells and complex cells are repeated after every 5 pixels. Given that an input image from the early visual system has size $162 \times 102$ and the size of a receptive field is $13 \times 13$, there are $27 \times 20=540$ locations that have simple cells and complex cells. Overall, there are $120 \times 540=64800$ simple cells and $30 \times 540=16200$ complex cells in total. For a given visual stimulus with size $170 \times 110$, complex cell responses can be represented by a $16200 \times 1$ vector. After the vision processing in V1, complex cell responses in $\mathrm{V} 1$ project to the RSC.

In this model, the V1-RSC network implements non-negative sparse coding. Similar to our previous work 


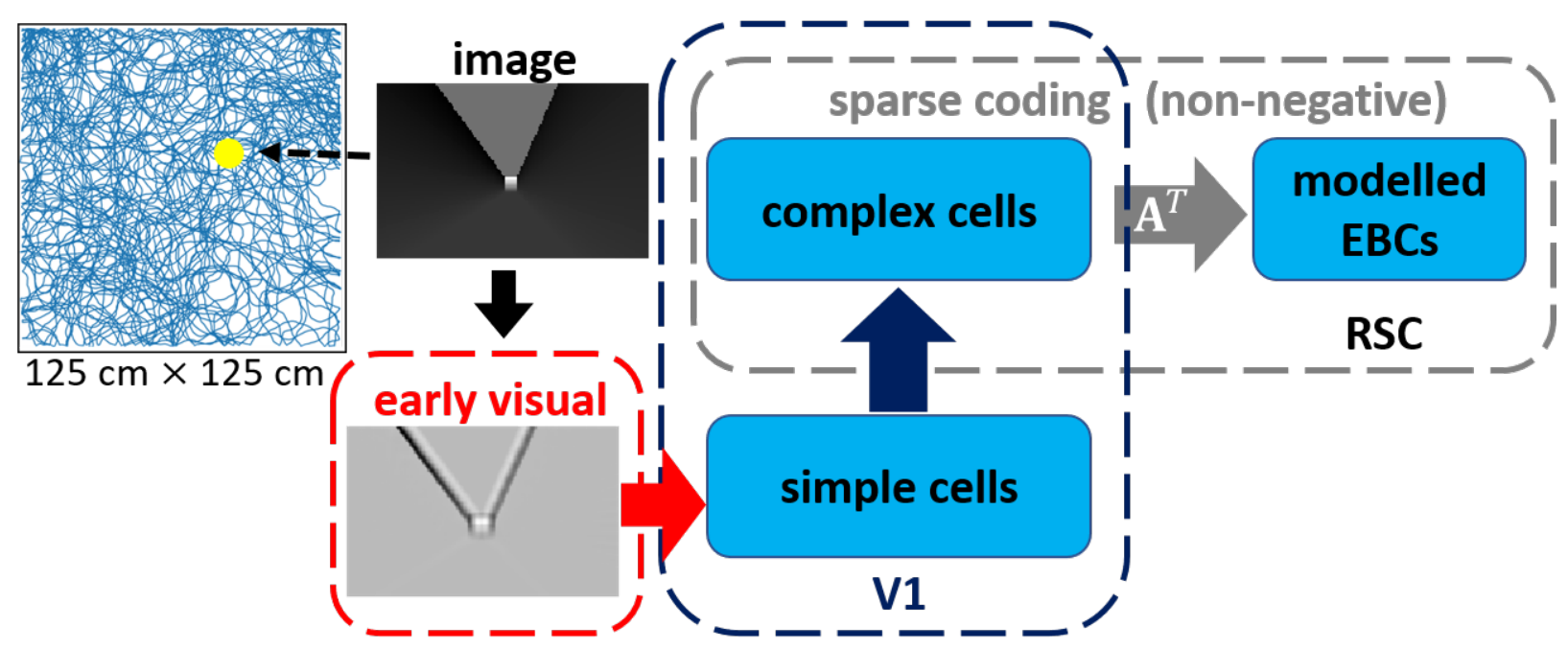

Figure 2: Structure of Model II. The virtual rat runs freely in the $125 \mathrm{~cm} \times 125 \mathrm{~cm}$ simulated environment. The simulated visual scene the animal sees at different locations is the input image to the early visual system. The processed visual input then projects to V1 and visual processing in V1 involves simple cell and then complex cell processing. Complex cells in V1 then project to modelled EBCs in RSC and a V1-RSC network is implemented based on non-negative sparse coding (Equations $3 \& 4$ ).

(Lian and Burkitt, 2021a,b), we implement the model via a locally competitive algorithm (Rozell et al., 2008) that efficiently solves sparse coding as follows:

$$
\begin{aligned}
\tau \dot{\mathbf{u}} & =-\mathbf{u}+\mathbf{A}^{T} \mathbf{I}-\mathbf{Y} \mathbf{s} \\
\mathbf{s} & =\max (\mathbf{u}-\lambda, 0)
\end{aligned}
$$

and

$$
\Delta \mathbf{A}=\eta(\mathbf{I}-\mathbf{A} \mathbf{s}) \mathbf{s}^{T} \text { with } \mathbf{A} \geq 0,
$$

where $\mathbf{I}$ is the input from V1 (i.e., complex cells responses), s represent the response (firing rate) of the neurons in the RSC, $\mathbf{u}$ can be interpreted as the corresponding membrane potential, $\mathbf{A}$ is the matrix containing basis vectors and can be interpreted as the connection weights between complex cells in V1 and neurons in the RSC, $\mathbf{Y}=\mathbf{A}^{T} \mathbf{A}-\mathbb{1}$ and can be interpreted as the recurrent connection between neurons in the RSC, $\mathbb{1}$ is the identity matrix, $\tau$ is the time constant of the RSC neurons, $\lambda$ is the positive sparsity constant that controls the threshold of firing, and $\eta$ is the learning rate. Each column of $\mathbf{A}$ is normalised to have length 1. Non-negativity of both $\mathbf{s}$ and $\mathbf{A}$ in Equations $3 \& 4$ is incorporated to implement non-negative sparse 
coding. Note the following correspondences between variables used in Model I (Equation 1) and Model II (Equation 3): the input $\mathbf{I}$ corresponds to $X$, the matrix $\mathbf{A}$, representing the connection strengths, corresponds to the variable $H$, and the vector $\mathbf{s}$ of neural responses corresponds to the variable $W$. Additional details about the above implementation of non-negative sparse coding can be found in Lian and Burkitt (2021a).

A derivation of the update equation for non-negative matrix factorisation (NNMF) from synaptic homeostasis and spike-time dependent plasticity is given by Carlson et al. (2013), in which they show the equivalence to the dictionary sparse coding method used in Section 2.2.

\subsubsection{Training}

For the implementation of this model, there are 100 model RSC neurons and the parameters are given below. For the model dynamics and learning rule described in Equations $3 \& 4, \tau$ is $10 \mathrm{~ms}, \lambda$ is 0 , and the time step of implementing the model dynamics is $0.5 \mathrm{~ms}$. The simulated visual input of the simulated trajectory that contains 40000 positions is used to train the model. Since the simulated trajectory is updated after every $30 \mathrm{~ms}$, at each position of the trajectory, there are 60 iterations of computing the model response using Equation 3. After these 60 iterations, the learning rule in Equation 4 is applied. The animal then moves to the next position of the simulated trajectory. The learning rate $\eta$ is set to 0.3 for the first $75 \%$ of the simulated trajectory and 0.03 for the final $25 \%$ of the simulated trajectory. Note that the model with $\lambda=0$ implements non-negative matrix factorisation (Lee and Seung, 1999), which is a special variant of non-negative sparse coding. However, when $\lambda$ is set to a positive value such as 0.1 , the learnt EBCs display similar features, except that the neural response is sparser.

\subsection{Collecting model data}

After Models I and II finish learning using simulated visual input sampled along the simulated trajectory, a testing trajectory with simulated visual input is used to collect model responses for further data analysis. The experimental trajectory of real rats from Alexander et al. (2020) is used as the testing trajectory and it contains movement direction as well as head direction. In addition, for the experimental trajectory, head direction is not necessarily identical to movement direction because the animal is not head-fixed in the experiment. Simulated visual input from the experimental trajectory is generated using the same approach 
described above, except that the camera is not facing front but aligned with the head direction from the experimental data. Both models are rate-based and thus the model responses are then transformed into spikes using a Poisson spike generator with a maximum firing rate $30 \mathrm{~Hz}$ for the whole modelled population.

Results displayed in the main text are generated using model data collected from an experimental trajectory that has different movement and head directions. However, results of model data collected from a simulated trajectory where head direction is aligned with movement direction are also given in Supplementary Material.

\subsection{Experimental methods}

An electrophysiological dataset collected from the RSC of male rats performing random foraging in a $125 \mathrm{~cm} \times 125 \mathrm{~cm}$ arena was used from published prior work (Alexander et al., 2020) to make comparisons between model and experiment data of EBCs. For additional details relating to experimental data acquisition see Alexander et al. (2020). In addition, the data analysis techniques from this experimental paper were used to analyze the data from the simulations.

\subsection{Data analysis}

\subsubsection{Two-dimensional (2D) spatial ratemaps and spatial stability}

The analysis of the neural activity in the simulation used the same techniques that were used to analyze published experimental data from retrosplenial cortex (Alexander et al., 2020). Animal or simulation positional occupancy within an open field was discretized into $3 \mathrm{~cm} \times 3 \mathrm{~cm}$ spatial bins. For each neuron, the raw firing rate for each spatial bin was calculated by dividing the number of spikes that occurred in a given bin by the amount of time the animal occupied that bin. Note that spiking in the model was generated by a Poisson spike generator. Raw firing rate maps were smoothed with a 2D Gaussian kernel spanning $3 \mathrm{~cm}$ to generate final rate maps for visualization. 


\subsubsection{Construction of egocentric boundary rate maps}

The analysis of egocentric boundary ratemaps (EBR) used the same techniques used for published experimental data (Alexander et al., 2020). EBRs were computed in a manner similar to 2D spatial ratemaps, but referenced relative to the animal rather than the spatial environment. The position of the boundaries relative to the animal was calculated for each position sample (i.e., frame). For each frame, we found the distance, in $2.5 \mathrm{~cm}$ bins, between arena boundaries and angles radiating from $0^{\circ}$ to $360^{\circ}$ in $3^{\circ}$ bins relative to the animal's position. Angular bins were referenced to the head direction of the animal such that $0^{\circ} / 360^{\circ}$ was always directly in front of the animal, $90^{\circ}$ to its left, $180^{\circ}$ directly behind it, and $270^{\circ}$ to its right. Intersections between each angle and environmental boundaries were only considered if the distance to intersection was less than or equal to half the length to the most distant possible boundary (in most cases this threshold was set at $62.5 \mathrm{~cm}$ or half the width of the arena to avoid ambiguity about the influence of opposite walls). In any frame, the animal occupied a specific distance and angle relative to multiple locations along the arena boundaries, and accordingly, for each frame, the presence of multiple boundary locations were added to multiple $3^{\circ} \times 2.5 \mathrm{~cm}$ bins in the egocentric boundary occupancy map. The same process was completed with the locations of individual spikes from each neuron, and an EBR was constructed by dividing the number of spikes in each $3^{\circ} \times 2.5 \mathrm{~cm}$ bin by the amount of time that bin was occupied in seconds. Smoothed EBRs were calculated by convolving each raw EBR with a 2D Gaussian kernel (5 bin width, 5 bin standard deviation).

\subsubsection{Identification of neurons with egocentric boundary vector tuning}

The identification of simulated neurons with significant egocentric boundary vector sensitivity used the same criteria for identification of real neurons showing this response (Alexander et al., 2020). The mean resultant (MR), $\bar{R}$, of the cell's egocentric boundary directional firing, collapsed across distance to the boundary, was calculated as

$$
\bar{R}=\left(\frac{1}{n m} \sum_{\theta=1}^{n} \sum_{D=1}^{m} F_{\theta, D} e^{i \theta}\right),
$$

where $\theta$ is the orientation relative to the rat, $D$ is the distance from the rat, $F_{\theta, D}$ is the firing rate in a given orientation-by-distance bin, $n$ is the number of orientation bins, and $m$ is the number of distance bins. The 
mean resultant length (MRL), $\bar{L}$, is defined as the absolute value of the mean resultant and characterized the strength of egocentric bearing tuning to environment boundaries. The preferred orientation of the egocentric boundary ratemap was calculated as the mean resultant angle (MRA), $\bar{\phi}$,

$$
\bar{\phi}=\arctan \left(\frac{\Im(\bar{R})}{\Re(\bar{R})}\right)
$$

where $\Im$ and $\Re$ are the real and imaginary parts of their arguments respectively.

The preferred distance was estimated by fitting a Weibull distribution to the firing rate vector corresponding to the MRA and finding the distance bin with the maximum firing rate. The MRL, MRA, and preferred distance were calculated for each neuron for the two halves of the experimental session independently.

A neuron was characterized as having egocentric boundary vector tuning (i.e., an EBC) if it reached the following criteria: 1) the MRL from both session halves were greater than the 99th percentile of the randomized distribution taken from Alexander et al. (2020) $(\bar{L}>0.14), 2)$ the absolute circular distance in preferred angle between the 1st and 2nd halves of the baseline session was less than $45^{\circ}$, and 3) the change in preferred distance for both the 1st and 2nd halves relative to the full session was less than $50 \%$. To refine our estimate of the preferred orientation and preferred distance of each neuron we calculated the center of mass (COM) of the receptive field defined after thresholding the entire EBR at $75 \%$ of the peak firing and finding the largest continuous contour ('contour' in Matlab). We repeated the same process for the inverse EBR for all cells to identify both an excitatory and inhibitory receptive field and corresponding preferred orientation and distance for each neuron.

\section{Results}

\subsection{Results using Model I - the Raw Visual Model}

100 dictionary elements (model cells) were learned using Model I on both the experimental trajectory and a simulated trajectory. $37 \%$ of these model cells possessed significant and reliable sensitivity to the egocentric bearing and distance to environmental boundaries. A similar but lightly larger percentage was observed when the model was tested on the simulated trajectory (41\%). Figure 3 shows six examples of learnt cells 
A
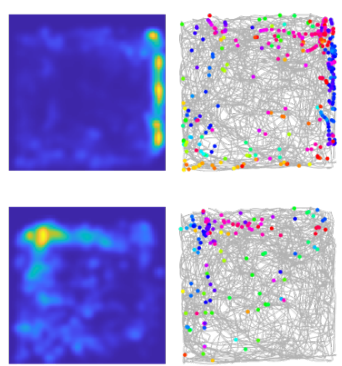
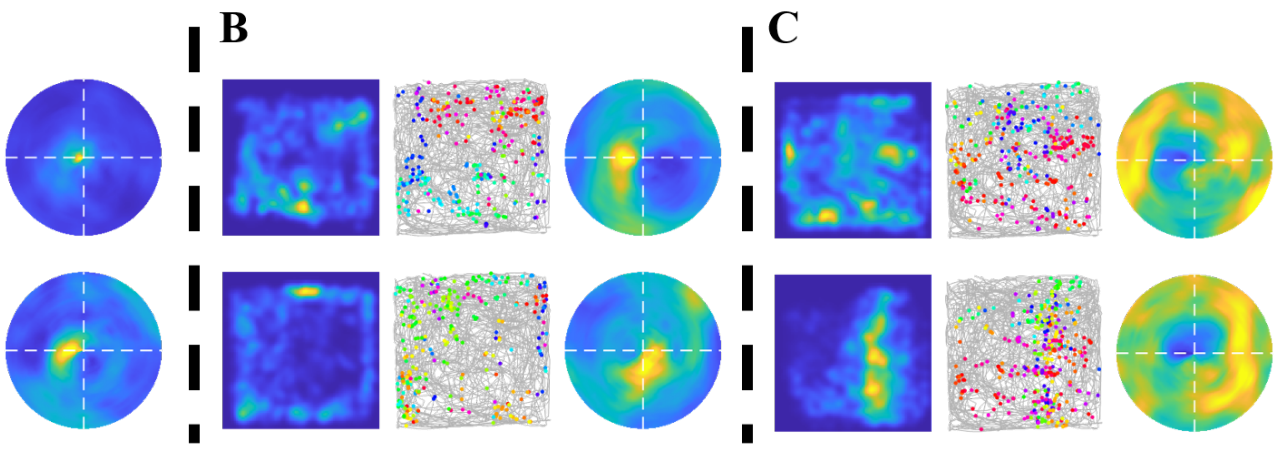

Figure 3: Examples of learnt EBCs recovered using experimental trajectory: Model I. Each row with three images shows the spatial rate map, firing plot with head directions and egocentric rate map (head directions as in Figure 1). (A) Proximal EBCs with different preferences of egocentric orientation. (B) Distal EBCs with different preferences of egocentric orientation. (C) Inverse EBCs.

\subsection{Results using Model II - the V1-RSC Model}

100 model cells were also trained using Model II on both the experimental trajectory and a simulated trajectory, as described in Section 2.3. Of these cells, $82 \%$ possessed significant egocentric boundary vector sensitivity when tested on the real animal trajectory and a similar percentage was observed on the simulated trajectory (90\%). Six examples showing the activity of cells with learned EBC receptive fields on the experimental trajectory are displayed in Figure 4. The two sets of plots in Figure 4A depict representative examples of proximal EBCs with two different preferences for egocentric orientation, and the two sets of plots in Figure 4B show representative examples of distal EBCs, also showing two different preferences for egocentric orientation. Each row consists of EBCs with similar orientations. These examples illustrate that they code for different orientations and distances in the animal-centered framework. The two sets of plots in Figure 4C show examples of learned inverse EBCs. Plots of the full set of 100 cells generated using Model I and using the experimental animal trajectory are given in the Supplementary Material A.3, and the 100 cells using the simulated animal trajectory are given in Supplementary Material A.4. 
These result show that, after training, the learnt RSC cells exhibit diverse egocentric tuning similar to that observed in experimental data (Alexander et al., 2020), including the three different types identified experimentally: proximal, distal and inverse. The results likewise show that the cells are activated by walls at different orientations in the egocentric framework. In other words, this model learns diverse egocentric vector coding; namely the learnt cells code for boundaries at different orientations and distances.
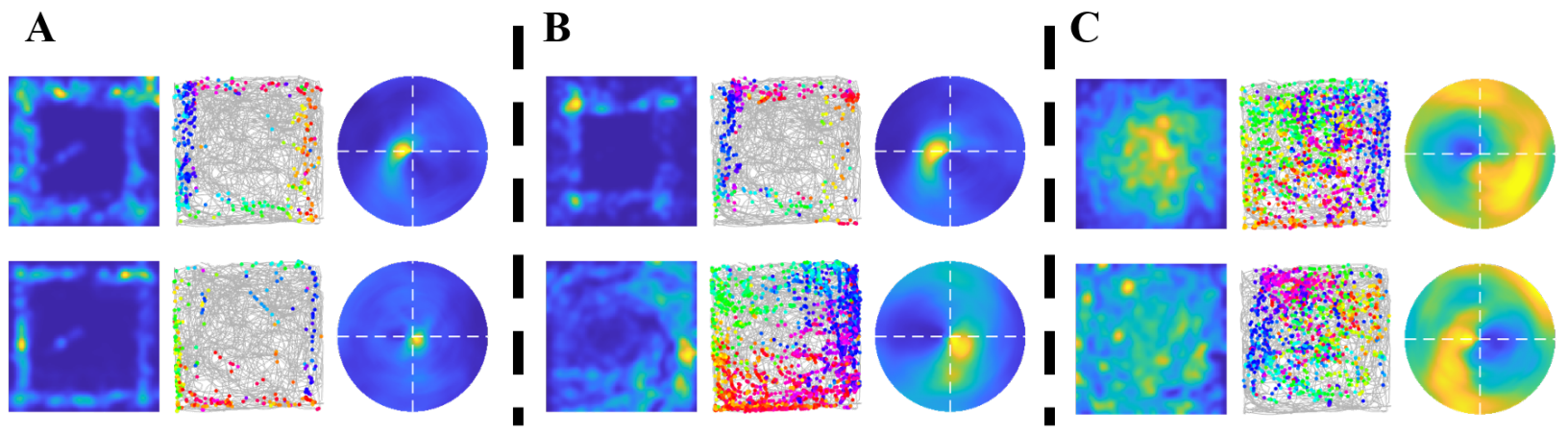

Figure 4: Examples of learnt EBCs recovered using experimental trajectory: Model II. Each row with three images shows the spatial rate map, firing plot with head directions and egocentric rate map (head directions as in Figure 1). (A) Proximal EBCs with different preferences of egocentric orientation. (B) Distal EBCs with different preferences of egocentric orientation. (C) Inverse EBCs.

\subsection{Population statistics of EBC orientation and distance}

The EBCs that are learnt using Models I \& II, illustrated in Figures $3 \& 4$ resp., show considerable similarity to those found in experimental studies (Alexander et al., 2020). The extent of the similarity is quantified by the population statistics, shown in Figure 5, which demonstrates that both Models I \& II generate EBCs whose characteristics resemble experimentally observed data on a population level. The vector coding of an EBC indicates the coding of orientation and distance. Experimental data (left of Figure 5) shows that EBCs in the RSC have a lateral preference for the orientation and a wide range of distance tuning. Learnt EBCs of both the raw visual model (Model I) and V1-RSC model (Model II) have similar distributions to the experimental data of both preferred bearing and distance, suggesting that visual input alone can give rise to the emergence of EBCs in the RSC through learning. 


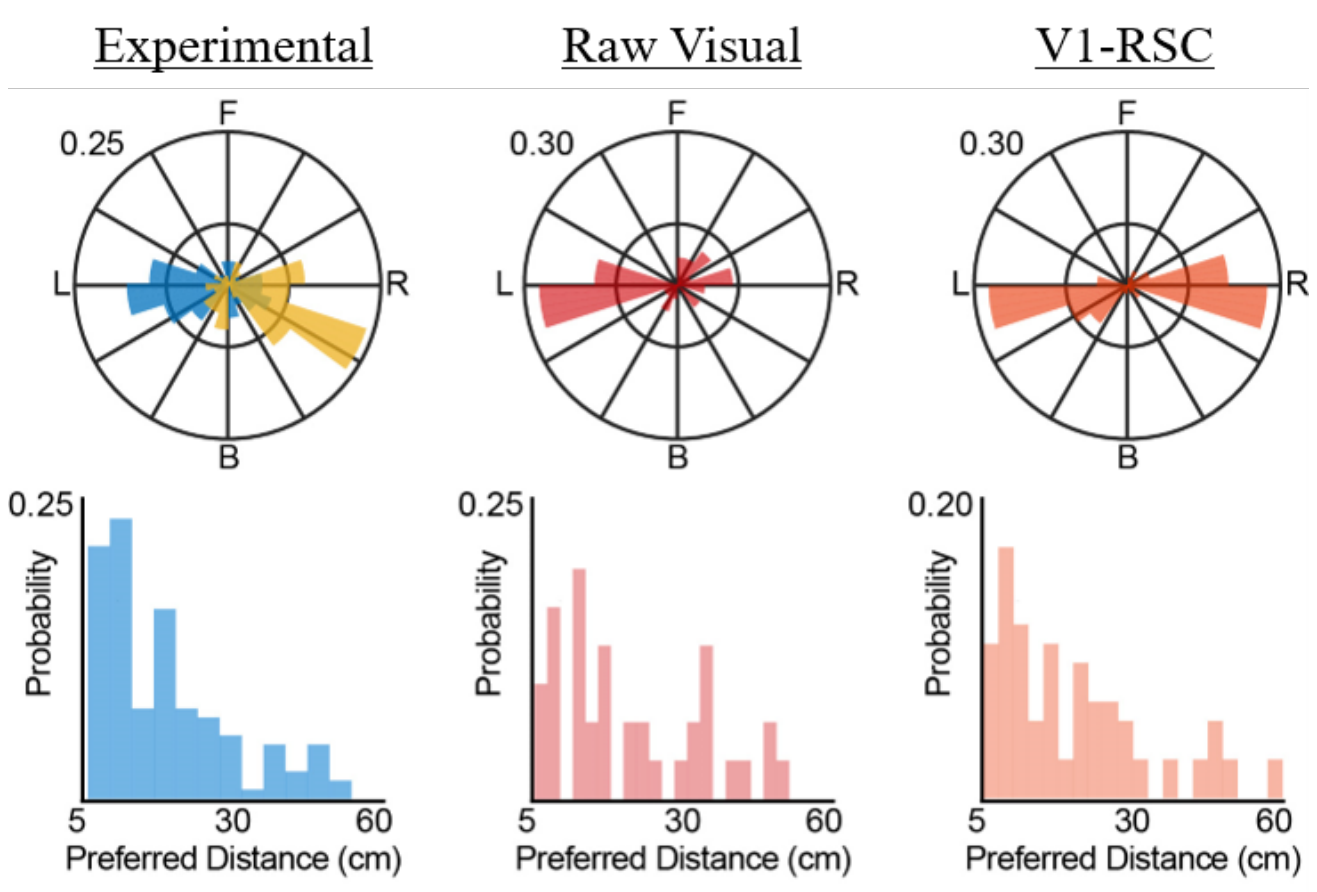

Figure 5: Population statistics of experimental and model data. Distributions of orientation (top row) and distance (bottom row) in the raw visual model (middle column, Model I) and V1-RSC model (right column, Model II) resemble experimental distributions observed in RSC (Alexander et al., 2020) (left column; blue and yellow histograms correspond to neurons recorded in the right and left hemispheres, respectively).

\section{Discussion}

In this study, the results of two different learning models for RSC cell responses are compared with experimental RSC cell data. Both models take visual images as the input, using trajectories of the environment that are either measured experimentally or simulated. The raw visual model (Model I) takes the raw visual images as the input, while the V1-RSC model (Model II) incorporates visual information processing associated with simple and complex cells of the primary visual cortex (Lian et al., 2019, 2021). After learning, both models generate EBCs that are proximal, distal and inverse, similar to experimentally observed EBCs in the RSC (Alexander et al., 2020). Furthermore, the learnt EBCs have similar distributions of orientation and distance coding to the distributions measured in experimental data, suggesting that visual input alone can account for the emergence of a special type of spatial cells in the navigational system of the brain egocentric boundary cells (EBCs). Differences between the responses in the two models also point to the effect that the processing of visual input carried out in the early visual pathway (retina to primary visual 
cortex) has upon RSC cell responses (Lian et al., 2019, 2021).

\subsection{Comparison between experimental and model data}

Though the model data indicates that both models can learn EBCs similar to experimental ones and the population statistics of orientation and distance coding resembles experimental data, there are still some important differences between model and experimental data that can shed light on the mechanisms associated with EBC responses. Experimental data shows that the orientation distribution is more skewed towards the back while the distributions of model data are more lateral. That the population responses for Model II lie between those of Model I and the experimental data seems to indicate that a major source of these differences is the extent to which the modelled visual input corresponds to that in the visual system. Whether more biophysically accurate simulated visual input could further reduce these differences is discussed in Section 4.2.
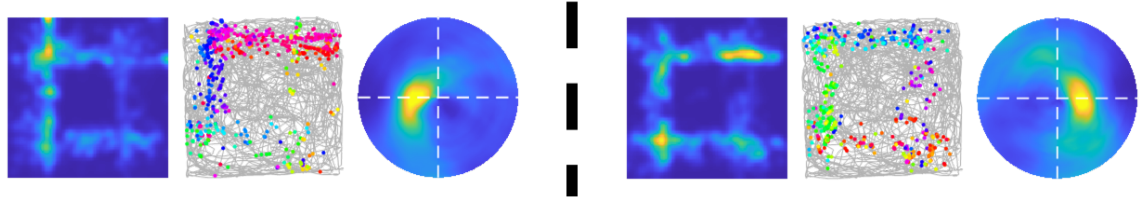

Figure 6: Examples of learnt EBCs that show overlapping wall response . Each row with three images shows the spatial rate map, firing plot with head directions and egocentric rate map. These two examples of learnt EBCs from Model II do not "cut off" the segments close to the corner such that the spatial rate maps have overlapping \#-like responses.

Additionally, there is still a substantial difference in how cells respond in the vicinity of corners of the environment. In simulation, some learnt EBCs show overlapping wall responses (see examples in Figure 6 and full model dataset in the Supplementary Material), whereas the experimental data seems to "cut off" the segments close to the corner. Our models only use visual input while the real animal integrates a variety of different sensory modalities into spatial coding. We infer that the integration of information from different sensory modalities could be responsible for cutting off the overlapping wall responses.

The percentage of EBCs for different data sets also differ. Alexander et al. (2020) reported 24.1\% $(n=134 / 555)$ EBCs in the experimental data. Model I (Raw Visual) has 41\% $(n=41 / 100)$ and 37\% $(n=37 / 100)$ EBCs recovered by simulated trajectory and experimental trajectory, respectively. Model II (V1-RSC) has 
90\% $(\mathrm{n}=90 / 100)$ and $82 \%(\mathrm{n}=82 / 100)$ EBCs recovered by simulated trajectory and experimental trajectory, respectively. The overall percentage of EBCs was lower in the experimental data than in both types of simulations. This likely arises from the focus of the simulations on coding of static visual input stimuli across a range of different positions and directions in the environment. Though the cells created by this focused simulation show striking similarity to real data, the retrosplenial cortex is clearly involved in additional dimensions of behavior such as the learning of specific trajectories and associations with specific landmarks. Previous recordings show that neurons in the retrosplenial cortex code additional features such as the position along a trajectory through the environment (Alexander and Nitz, 2015, 2017; Mao et al., 2018, 2020) and the relationship of landmarks to head direction (Jacob et al., 2017; Lozano et al., 2017; Fischer et al., 2020).

Human functional imaging also demonstrates coding of position along a trajectory (Chrastil et al., 2015) as well as the relationship of spatial landmarks to specific memories (Epstein et al., 2007). The neuronal populations involved in these additional functions of retrosplenial cortex are not included in the model, which could account for the EBCs making up a larger percentage of the neurons in the simulations.

\subsection{Rat vision processing}

Rats have very different vision from humans, in part because their eyes are positioned on the side of their head, whereas human's eyes are facing front. Consequently rats have a wide visual field and a strong lateral vision. In this study, rat vision is simulated by a camera with a $170^{\circ}$ horizontal view and $110^{\circ}$ vertical view. Though the view angle is wider compared with human vision, the simulated vision might not be as lateral as real rats. In our simulations, when the horizontal view was set to $120^{\circ}$, the learnt $\mathrm{EBCs}$ were mostly observed to be in front of the animal, i.e., the orientation distribution is clustered in the upper half of the distribution polar plot (data not shown). Somewhat surprisingly, the $170^{\circ}$ horizontal view leads to more laterally distributed EBCs that resembles the orientation distribution of experimental data, though the simulated vision may not be as lateral as in rats. Therefore, our models suggest that the properties of learnt EBCs are strongly determined by the size of the rat visual field. Due to the built-in limitations of the Panda3D game engine used to simulate the visual input, we were unable to generate visual input at degrees more lateral than the 170 degree range used here. This will be investigated in future studies, in which the rat 
vision will be mimicked by simulating visual input using two laterally positioned cameras.

\subsection{Differences between raw visual model (Model I) and V1-RSC model (Model II)}

Both Models I \& II take the visual input and generate EBC response using learning methods based on the principle of sparse coding. However, there are significant differences between the two models. The raw visual model (Model I) takes the raw image as the input while the V1-RSC model (Model II) incorporates vision processing similar to that of the brain that detects lines or edges in the visual input. In other words, Model I learns cells based on the individual pixel intensities while Model II learns cells based on the existence of visual features such as lines or edges. Because the environment consists of three black walls and one white wall, this difference may result in the white wall affecting Model I more than Model II. In particular, this could explain why the learnt EBCs of Model II tend to be more omnidirectional in their firing for all four walls compared with Model I (see examples of both models in Supplementary Material), which may be related to the role of RSC as the egocentric-allocentric "transformation circuit" proposed by Byrne et al. (2007) and Bicanski and Burgess (2018).

Another difference lies in the percentage of learnt EBCs between two models where Model II learns more EBCs (see "Comparison between experimental and model data", Section 4.1, above). We infer that this difference also originates from different visual input processing by the models.

\section{References}

Alexander, A. S., Carstensen, L. C., Hinman, J. R., Raudies, F., Chapman, G. W., and Hasselmo, M. E. (2020). Egocentric boundary vector tuning of the retrosplenial cortex. Sci. Adv., 6(8):eaaz2322.

Alexander, A. S. and Nitz, D. A. (2015). Retrosplenial cortex maps the conjunction of internal and external spaces. Nat. Neurosci., 18(8):1143-1151.

Alexander, A. S. and Nitz, D. A. (2017). Spatially periodic activation patterns of retrosplenial cortex encode route sub-spaces and distance traveled. Curr. Biol., 27(11):1551-1560.

Beyeler, M., Rounds, E. L., Carlson, K. D., Dutt, N., and Krichmar, J. L. (2019). Neural correlates of sparse coding and dimensionality reduction. PLoS Comput. Biol., 15(6):e1006908. 
Bicanski, A. and Burgess, N. (2018). A neural-level model of spatial memory and imagery. eLife, 7:e33752.

Bicanski, A. and Burgess, N. (2020). Neuronal vector coding in spatial cognition. Nat. Rev. Neurosci., 21(9):453-470.

Borghuis, B., Ratliff, C., Smith, R., Sterling, P., and Balasubramanian, V. (2008). Design of a neuronal array. J. Neurosci., 28(12):3178-3189.

Byrne, P., Becker, S., and Burgess, N. (2007). Remembering the past and imagining the future: a neural model of spatial memory and imagery. Psychol. Rev., 114(2):340.

Carandini, M. (2006). What simple and complex cells compute. J. Physiol., 577(2):463-466.

Carlson, K. D., Richert, M., Dutt, N., and Krichmar, J. L. (2013). Biologically plausible models of homeostasis and STDP: stability and learning in spiking neural networks. In The 2013 International Joint Conference on Neural Networks (IJCNN), pages 1-8. IEEE.

Chrastil, E. R., Sherrill, K. R., Hasselmo, M. E., and Stern, C. E. (2015). There and back again: hippocampus and retrosplenial cortex track homing distance during human path integration. J. Neurosci., 35(46):1544215452.

Epstein, R. A., Parker, W. E., and Feiler, A. M. (2007). Where am I now? Distinct roles for parahippocampal and retrosplenial cortices in place recognition. J. Neurosci., 27(23):6141-6149.

Fischer, L. F., Soto-Albors, R. M., Buck, F., and Harnett, M. T. (2020). Representation of visual landmarks in retrosplenial cortex. eLife, 9:e51458.

Gofman, X., Tocker, G., Weiss, S., Boccara, C. N., Lu, L., Moser, M.-B., Moser, E. I., Morris, G., and Derdikman, D. (2019). Dissociation between postrhinal cortex and downstream parahippocampal regions in the representation of egocentric boundaries. Curr. Biol., 29(16):2751-2757.

Hafting, T., Fyhn, M., Molden, S., Moser, M.-B., and Moser, E. I. (2005). Microstructure of a spatial map in the entorhinal cortex. Nature, 436(7052):801-806.

Hinman, J. R., Brandon, M. P., Climer, J. R., Chapman, G. W., and Hasselmo, M. E. (2016). Multiple running speed signals in medial entorhinal cortex. Neuron, 91(3):666-679. 
Hinman, J. R., Chapman, G. W., and Hasselmo, M. E. (2019). Neuronal representation of environmental boundaries in egocentric coordinates. Nat. Commun., 10(1):1-8.

Hoyer, P. O. (2003). Modeling receptive fields with non-negative sparse coding. Neurocomputing, 52:547552.

Jacob, P.-Y., Casali, G., Spieser, L., Page, H., Overington, D., and Jeffery, K. (2017). An independent, landmark-dominated head-direction signal in dysgranular retrosplenial cortex. Nat. Neurosci., 20(2):173175.

Kropff, E., Carmichael, J. E., Moser, M.-B., and Moser, E. I. (2015). Speed cells in the medial entorhinal cortex. Nature, 523(7561):419-424.

LaChance, P. A., Todd, T. P., and Taube, J. S. (2019). A sense of space in postrhinal cortex. Science, 365(6449):eaax4192.

Lee, D. D. and Seung, H. S. (1999). Learning the parts of objects by non-negative matrix factorization. Nature, 401(6755):788-791.

Lever, C., Burton, S., Jeewajee, A., O'Keefe, J., and Burgess, N. (2009). Boundary vector cells in the subiculum of the hippocampal formation. J. Neurosci., 29(31):9771-9777.

Lian, Y., Almasi, A., Grayden, D. B., Kameneva, T., Burkitt, A. N., and Meffin, H. (2021). Learning receptive field properties of complex cells in V1. PLoS Comput. Biol., 17(3):e1007957.

Lian, Y. and Burkitt, A. N. (2021a). Learning an efficient hippocampal place map from entorhinal inputs using non-negative sparse coding. eNeuro, 8(4):1-19.

Lian, Y. and Burkitt, A. N. (2021b). Learning spatio-temporal properties of hippocampal place cells. bioRxiv, doi:10.1101/2021.07.13.452268.

Lian, Y., Grayden, D. B., Kameneva, T., Meffin, H., and Burkitt, A. N. (2019). Toward a biologically plausible model of LGN-V1 pathways based on efficient coding. Front. Neural Circuits, 13:13.

Lozano, Y. R., Page, H., Jacob, P.-Y., Lomi, E., Street, J., and Jeffery, K. (2017). Retrosplenial and post- 
subicular head direction cells compared during visual landmark discrimination. Brain Neurosci. Adv., $1: 1-17$.

Mao, D., Molina, L. A., Bonin, V., and McNaughton, B. L. (2020). Vision and locomotion combine to drive path integration sequences in mouse retrosplenial cortex. Curr. Biol., 30(9):1680-1688.

Mao, D., Neumann, A. R., Sun, J., Bonin, V., Mohajerani, M. H., and McNaughton, B. L. (2018). Hippocampus-dependent emergence of spatial sequence coding in retrosplenial cortex. Proc. Natl. Acad. Sci. USA, 115(31):8015-8018.

Movshon, J., Thompson, I., and Tolhurst, D. (1978a). Receptive field organization of complex cells in the cat's striate cortex. J. Physiol., 283(1):79-99.

Movshon, J., Thompson, I., and Tolhurst, D. (1978b). Spatial summation in the receptive fields of simple cells in the cat's striate cortex. J. Physiol., 283(1):53-77.

O'Keefe, J. (1976). Place units in the hippocampus of the freely moving rat. Exp. Neurol., 51(1):78-109.

O'Keefe, J. and Dostrovsky, J. (1971). The hippocampus as a spatial map: preliminary evidence from unit activity in the freely-moving rat. Brain Res., 34:171-175.

Olshausen, B. A. and Field, D. J. (1996). Emergence of simple-cell receptive field properties by learning a sparse code for natural images. Nature, 381(6583):607-609.

Olshausen, B. A. and Field, D. J. (1997). Sparse coding with an overcomplete basis set: A strategy employed by V1? Vision Res., 37(23):3311-3325.

Pedregosa, F., Varoquaux, G., Gramfort, A., Michel, V., Thirion, B., Grisel, O., Blondel, M., Prettenhofer, P., Weiss, R., Dubourg, V., et al. (2011). Scikit-learn: Machine learning in Python. J. Mach. Learn. Res., $12: 2825-2830$.

Prusky, G. T., West, P. W., and Douglas, R. M. (2000). Behavioral assessment of visual acuity in mice and rats. Vision Res., 40(16):2201-2209.

Ratliff, C., Borghuis, B., Kao, Y., Sterling, P., and Balasubramanian, V. (2010). Retina is structured to process an excess of darkness in natural scenes. Proc. Natl. Acad. Sci. USA, 107(40):17368-17373. 
Raudies, F. and Hasselmo, M. E. (2012). Modeling boundary vector cell firing given optic flow as a cue. PLoS Comput. Biol., 8(6):e1002553.

Rozell, C. J., Johnson, D. H., Baraniuk, R. G., and Olshausen, B. A. (2008). Sparse coding via thresholding and local competition in neural circuits. Neural Comput., 20(10):2526-2563.

Solstad, T., Boccara, C. N., Kropff, E., Moser, M.-B., and Moser, E. I. (2008). Representation of geometric borders in the entorhinal cortex. Science, 322(5909):1865-1868.

Stensola, H., Stensola, T., Solstad, T., Frøland, K., Moser, M.-B., and Moser, E. I. (2012). The entorhinal grid map is discretized. Nature, 492(7427):72-78.

Tadmor, Y. and Tolhurst, D. (2000). Calculating the contrasts that retinal ganglion cells and LGN neurones encounter in natural scenes. Vision Res., 40(22):3145-3157.

Taube, J. S., Muller, R. U., and Ranck, J. B. (1990a). Head-direction cells recorded from the postsubiculum in freely moving rats. I. Description and quantitative analysis. J. Neurosci., 10(2):420-435.

Taube, J. S., Muller, R. U., and Ranck, J. B. (1990b). Head-direction cells recorded from the postsubiculum in freely moving rats. II. Effects of environmental manipulations. J. Neurosci., 10(2):436-447.

Troy, J., Oh, J., and Enroth-Cugell, C. (1993). Effect of ambient illumination on the spatial properties of the center and surround of Y-cell receptive fields. Vis. Neurosci., 10(4):753-764.

Wang, C., Chen, X., Lee, H., Deshmukh, S. S., Yoganarasimha, D., Savelli, F., and Knierim, J. J. (2018). Egocentric coding of external items in the lateral entorhinal cortex. Science, 362(6417):945-949. 
bioRxiv preprint doi: https://doi.org/10.1101/2022.01.28.478267; this version posted January 29, 2022. The copyright holder for this preprint (which was not certified by peer review) is the author/funder, who has granted bioRxiv a license to display the preprint in perpetuity. It is made available under aCC-BY-NC 4.0 International license.

\section{${ }_{454}$ A Supplementary Material}

455 This section provides all learnt cells of both Models recovered by simulated and experimental trajectories.

456 Each row with three images below and in the following subsections shows the spatial rate map, firing plot

457 with head directions and egocentric rate map. 
bioRxiv preprint doi: https://doi.org/10.1101/2022.01.28.478267; this version posted January 29, 2022. The copyright holder for this preprint (which was not certified by peer review) is the author/funder, who has granted bioRxiv a license to display the preprint in perpetuity. It is made available under aCC-BY-NC 4.0 International license.

\section{A.1 All learnt cells of Model I using experimental trajectory}
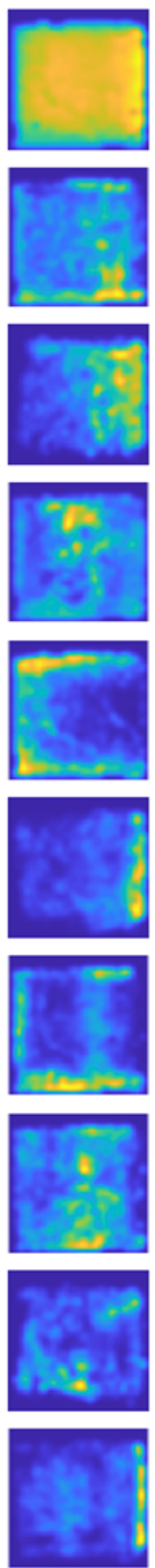
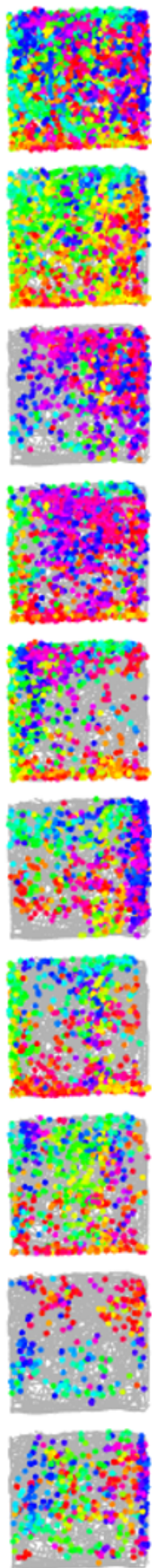
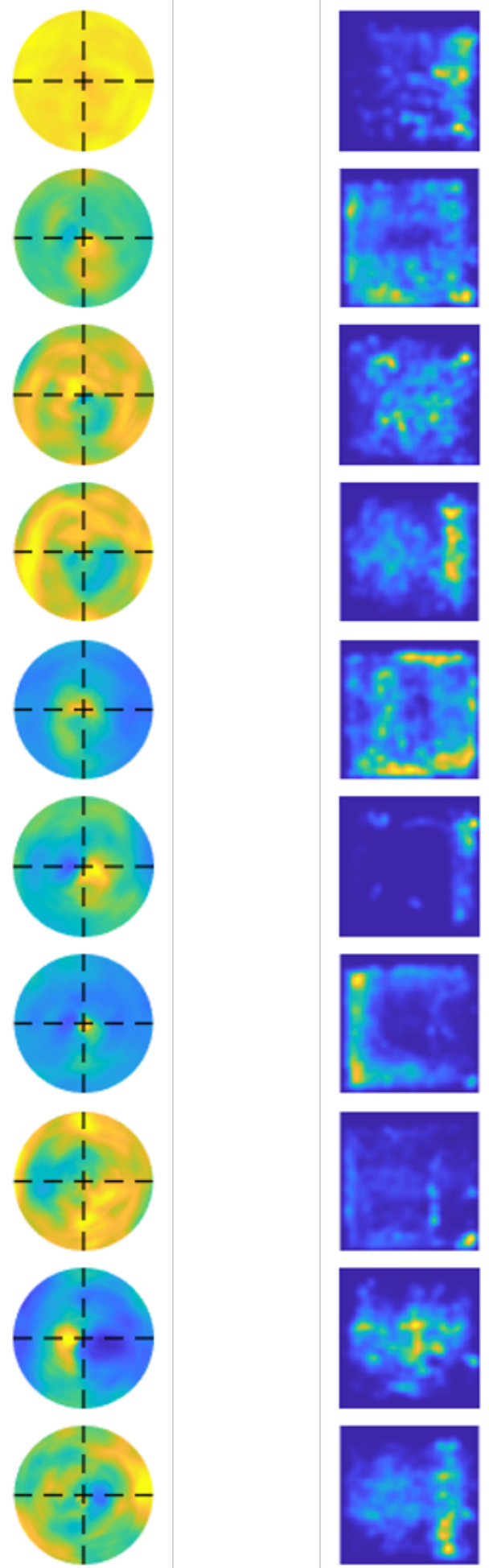
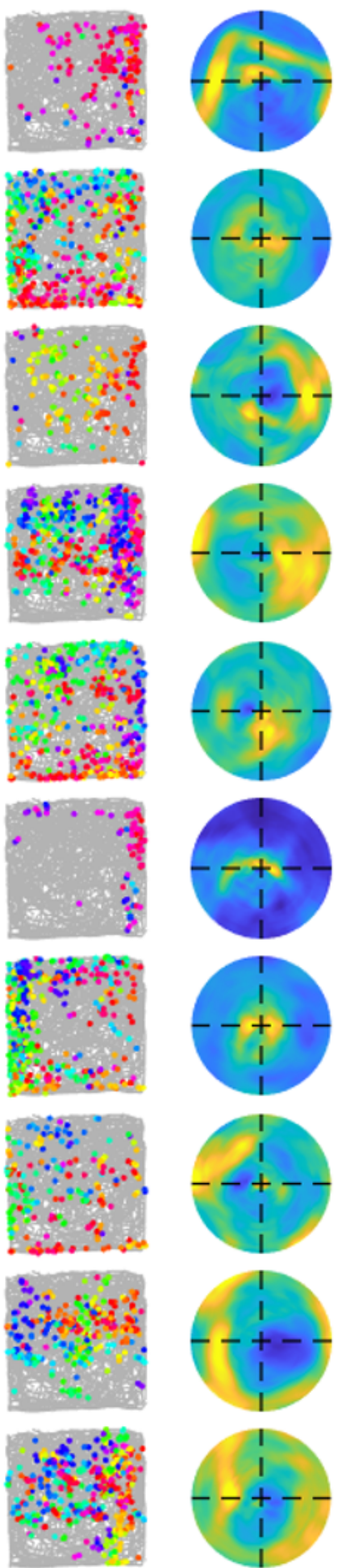
bioRxiv preprint doi: https://doi.org/10.1101/2022.01.28.478267; this version posted January 29, 2022. The copyright holder for this preprint (which was not certified by peer review) is the author/funder, who has granted bioRxiv a license to display the preprint in perpetuity. It is made available under aCC-BY-NC 4.0 International license.
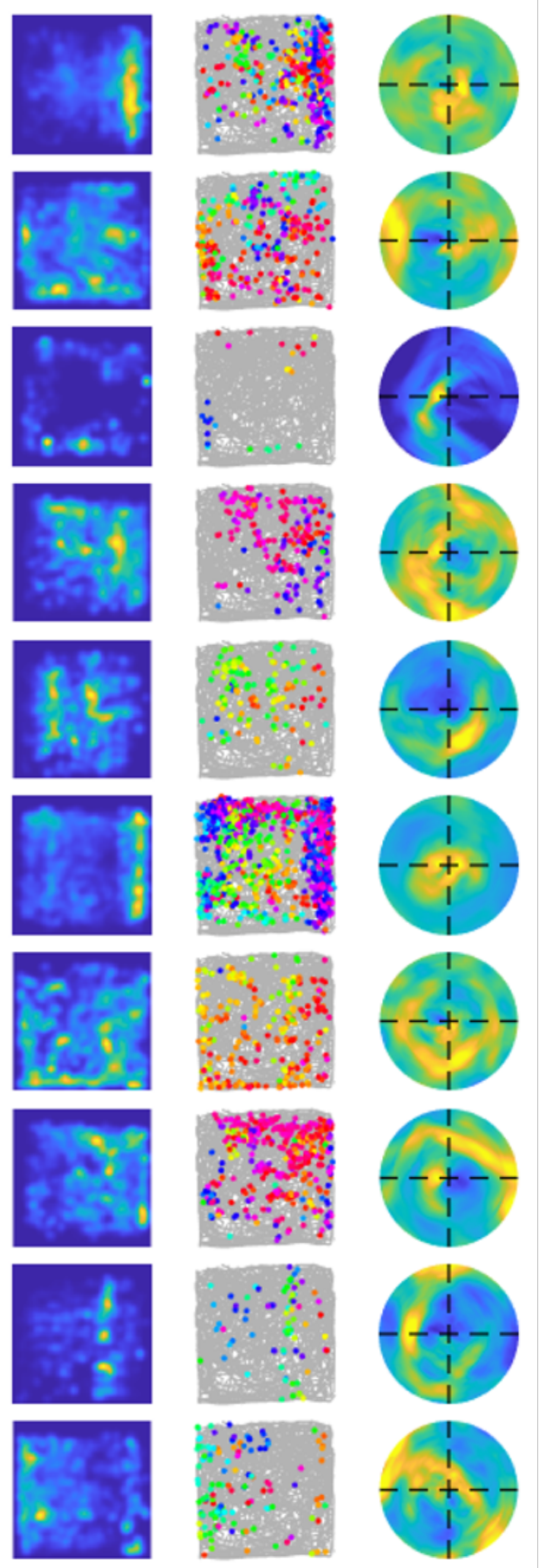
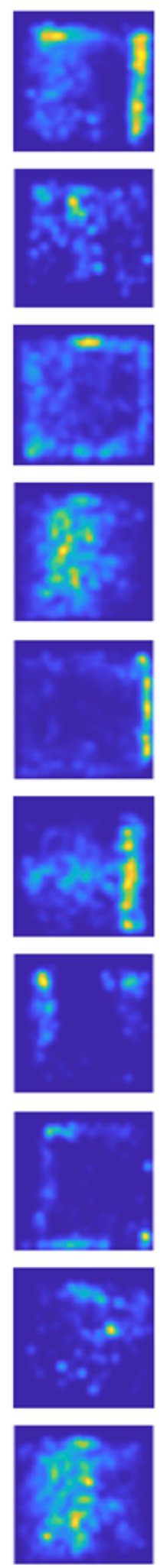
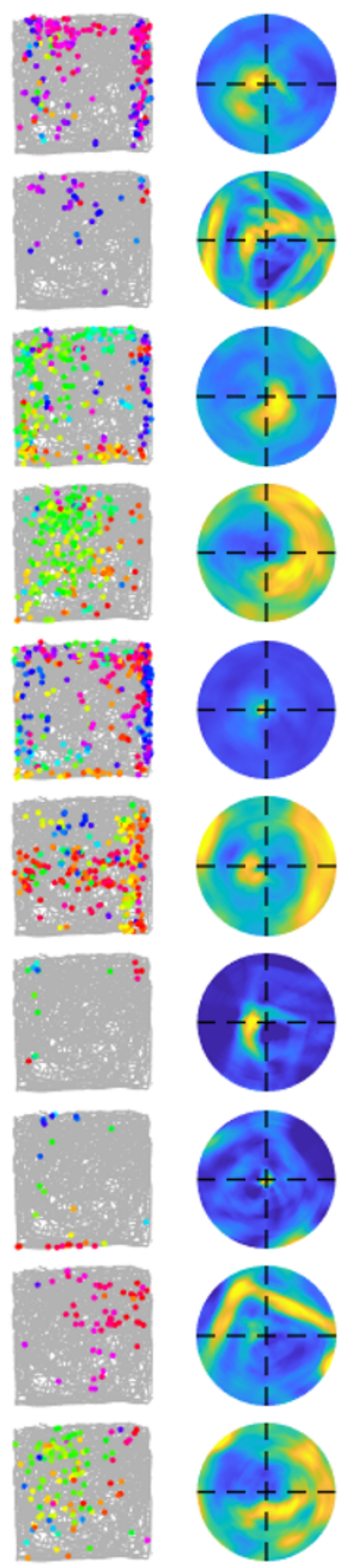
bioRxiv preprint doi: https://doi.org/10.1101/2022.01.28.478267; this version posted January 29, 2022. The copyright holder for this preprint (which was not certified by peer review) is the author/funder, who has granted bioRxiv a license to display the preprint in perpetuity. It is made available under aCC-BY-NC 4.0 International license.
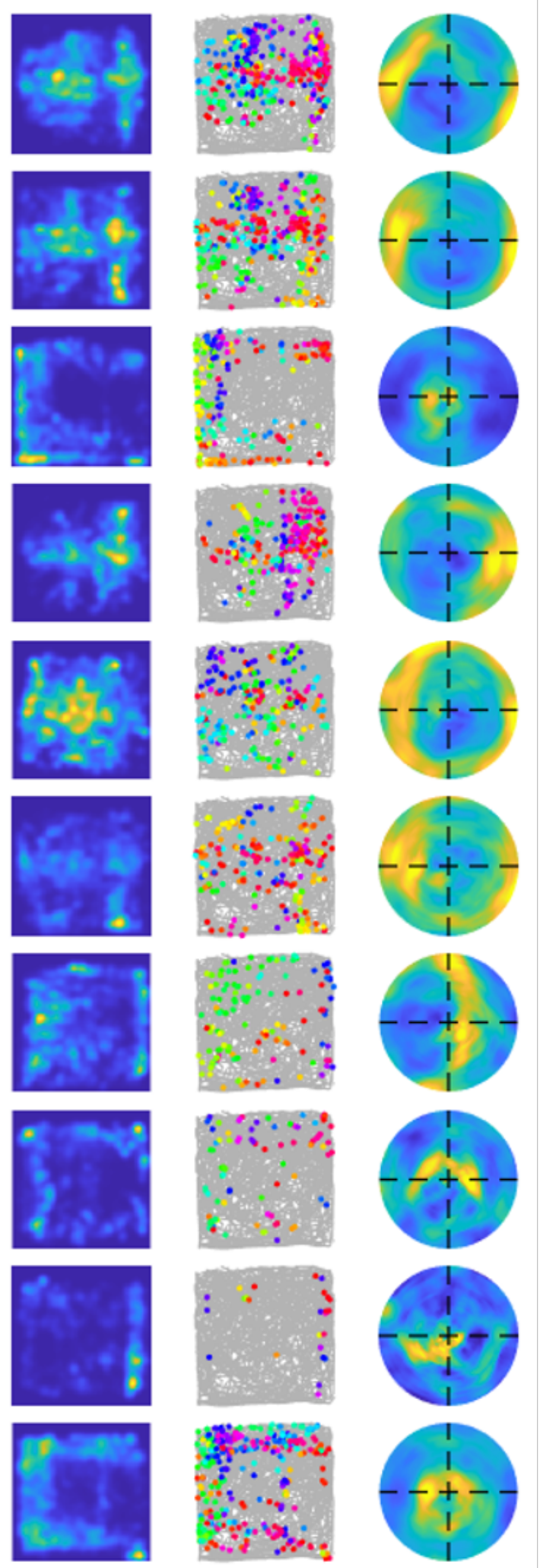
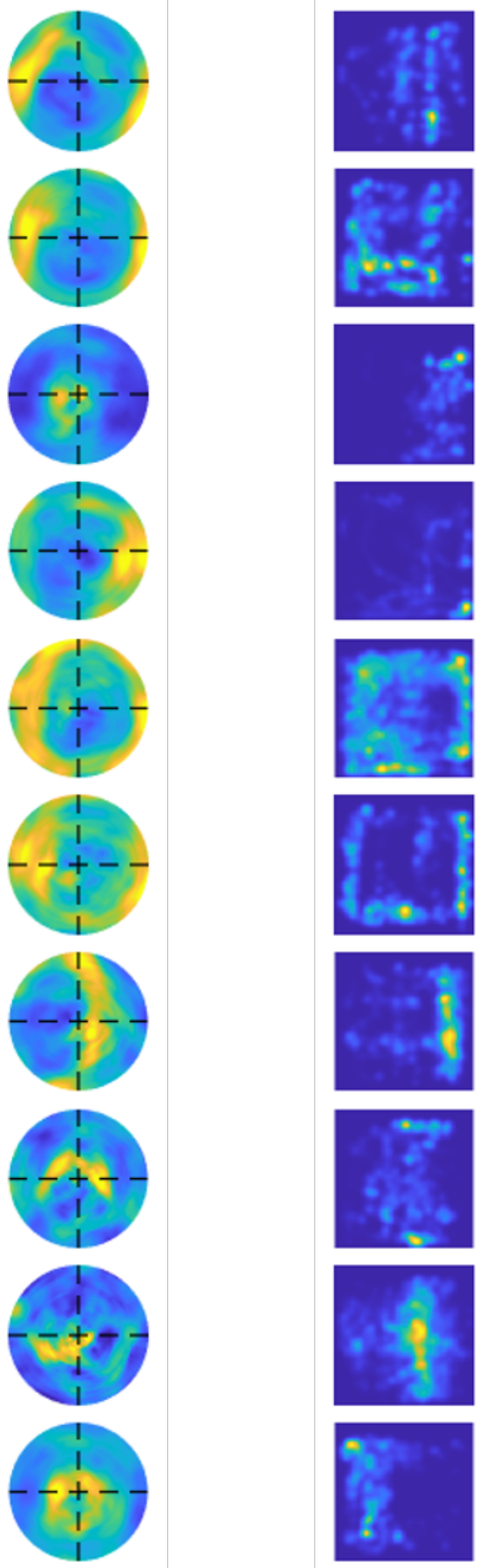
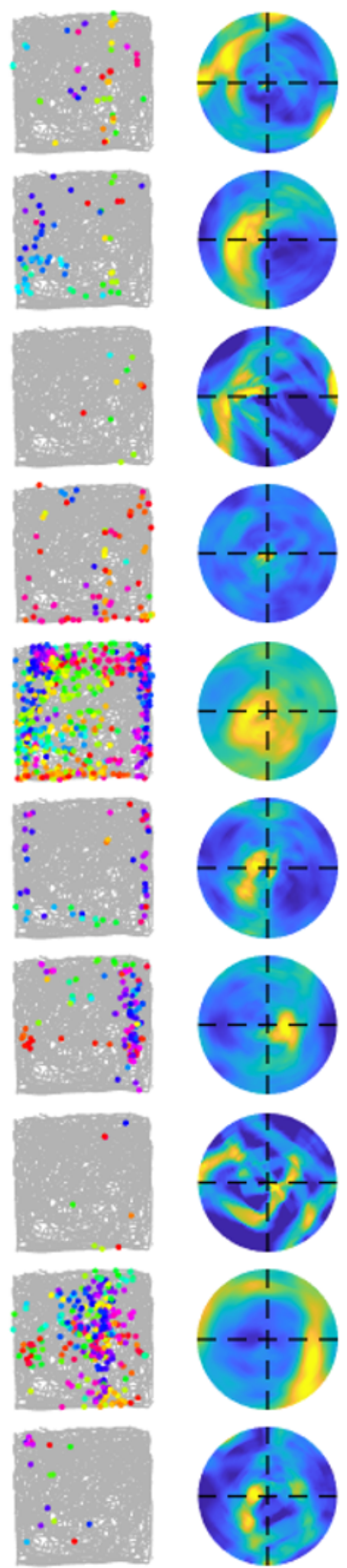
bioRxiv preprint doi: https://doi.org/10.1101/2022.01.28.478267; this version posted January 29, 2022. The copyright holder for this preprint (which was not certified by peer review) is the author/funder, who has granted bioRxiv a license to display the preprint in perpetuity. It is made available under aCC-BY-NC 4.0 International license.
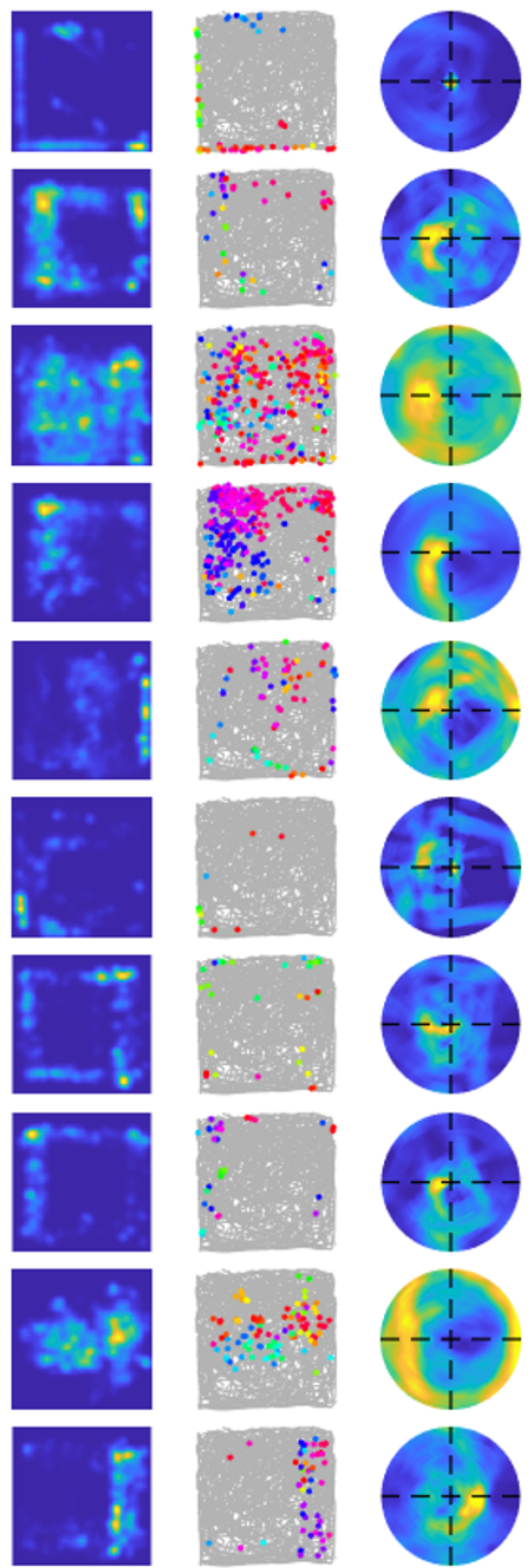
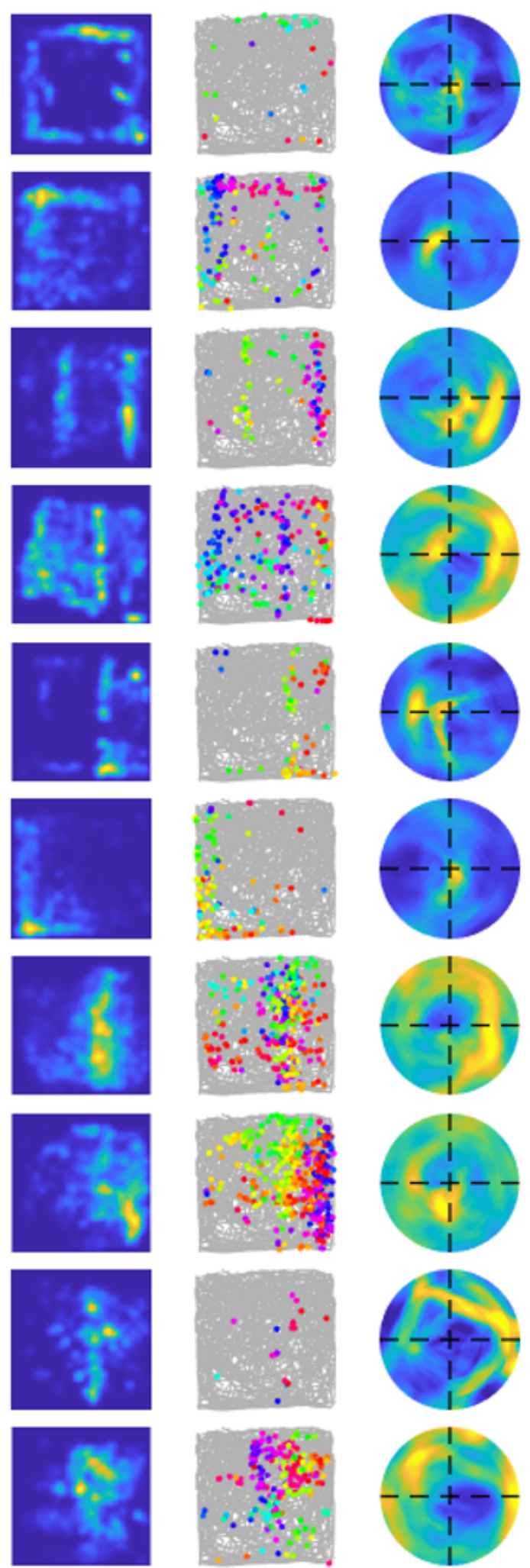
bioRxiv preprint doi: https://doi.org/10.1101/2022.01.28.478267; this version posted January 29, 2022. The copyright holder for this preprint (which was not certified by peer review) is the author/funder, who has granted bioRxiv a license to display the preprint in perpetuity. It is made available under aCC-BY-NC 4.0 International license.
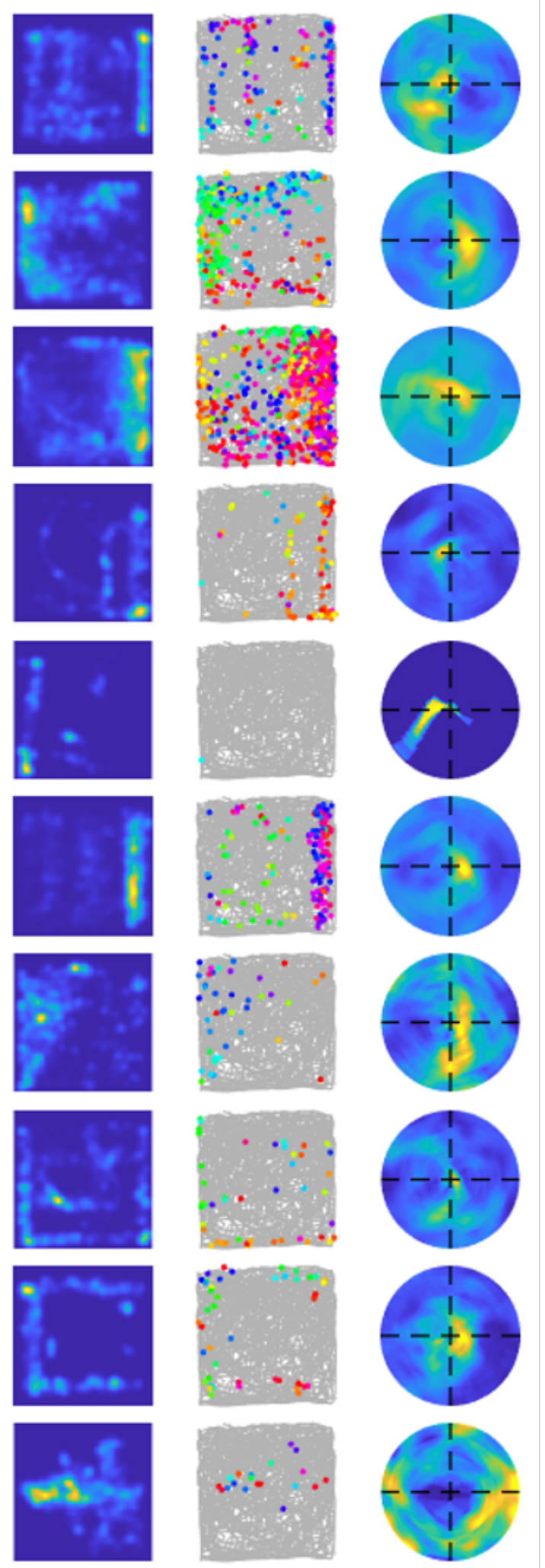
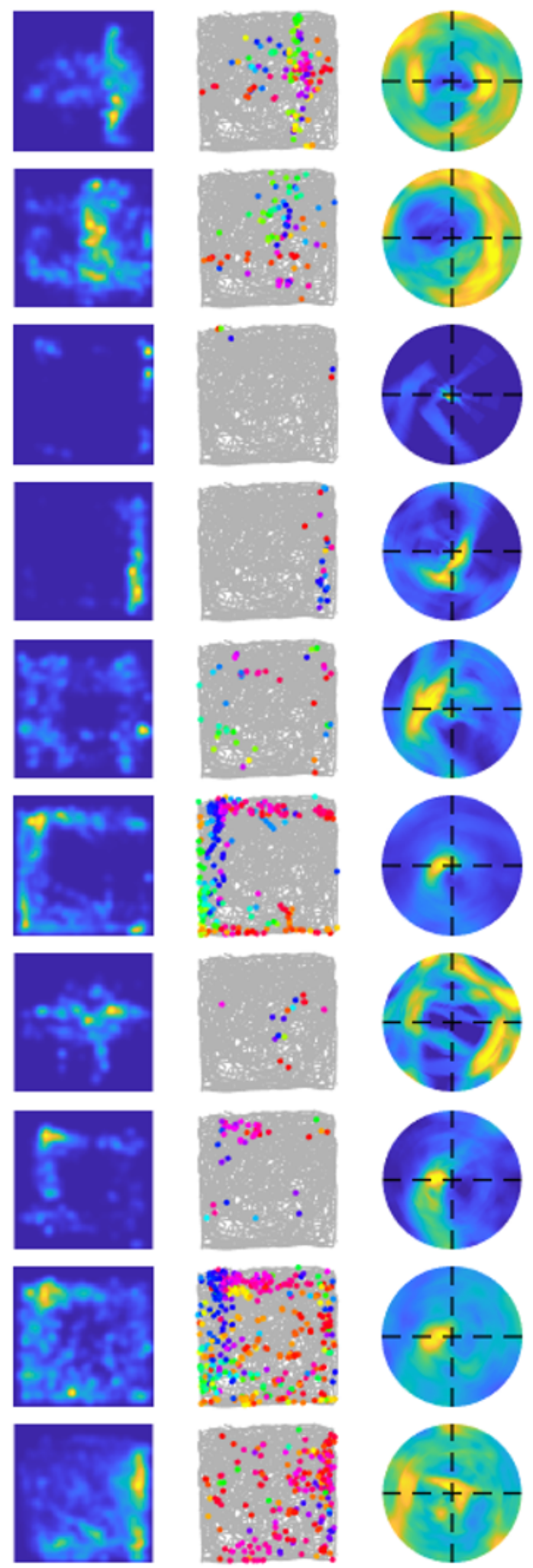
bioRxiv preprint doi: https://doi.org/10.1101/2022.01.28.478267; this version posted January 29, 2022. The copyright holder for this preprint (which was not certified by peer review) is the author/funder, who has granted bioRxiv a license to display the preprint in perpetuity. It is made available under aCC-BY-NC 4.0 International license.

\section{A.2 All learnt cells of Model I using simulated trajectory}
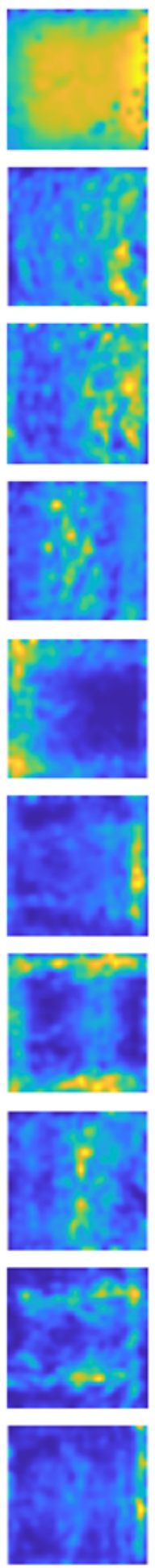
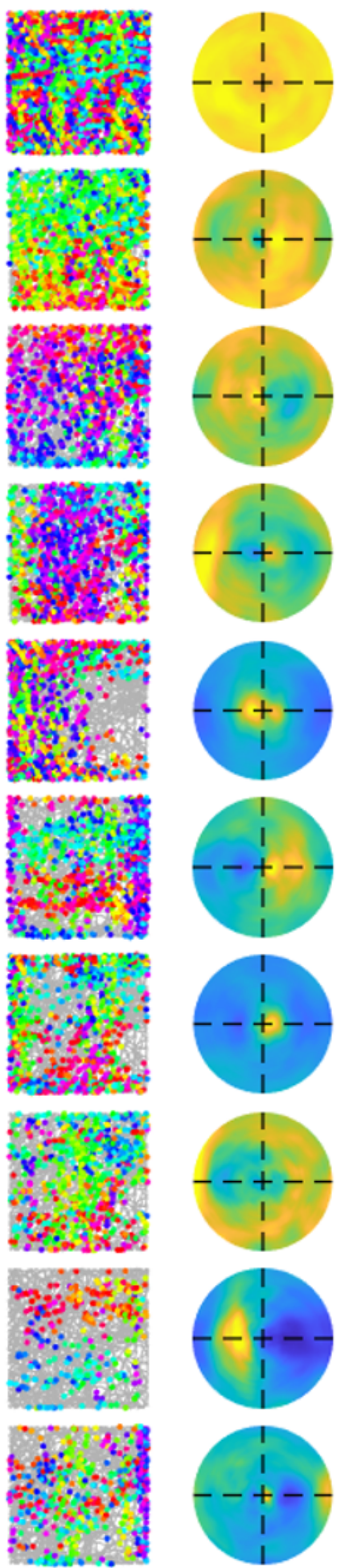
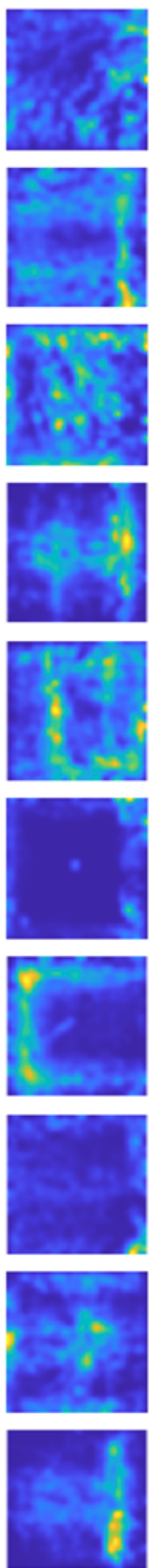
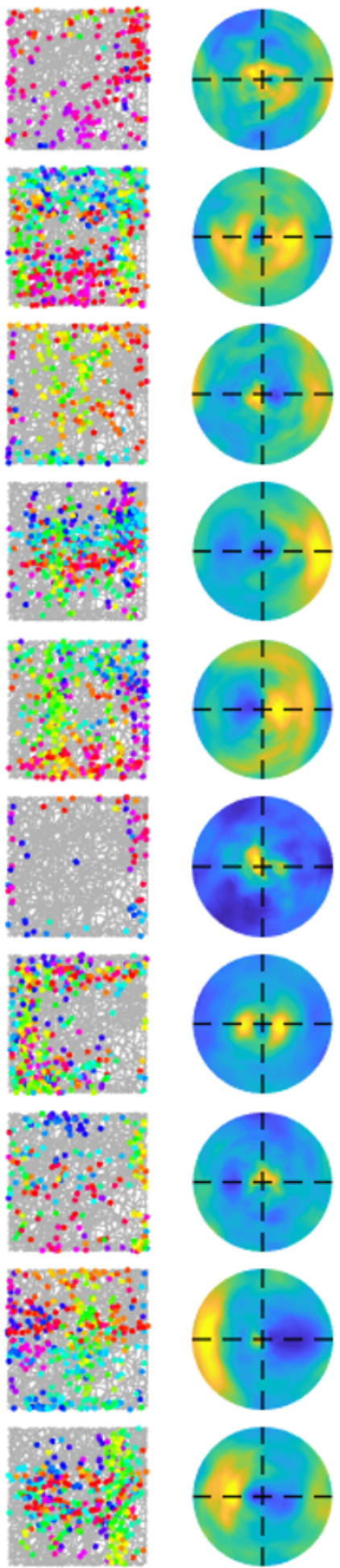
bioRxiv preprint doi: https://doi.org/10.1101/2022.01.28.478267; this version posted January 29, 2022. The copyright holder for this preprint (which was not certified by peer review) is the author/funder, who has granted bioRxiv a license to display the preprint in perpetuity. It is made available under aCC-BY-NC 4.0 International license.
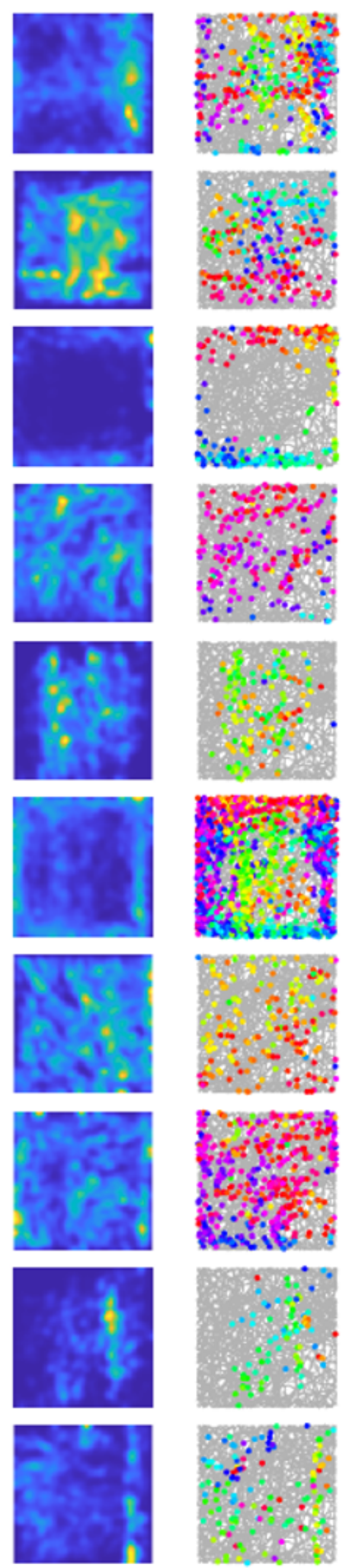

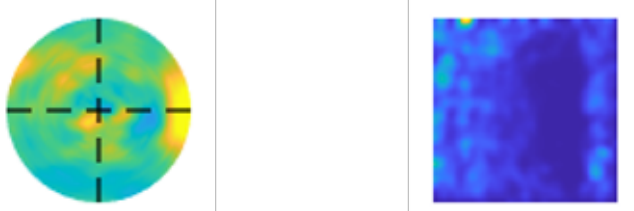

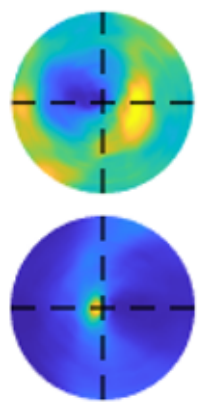
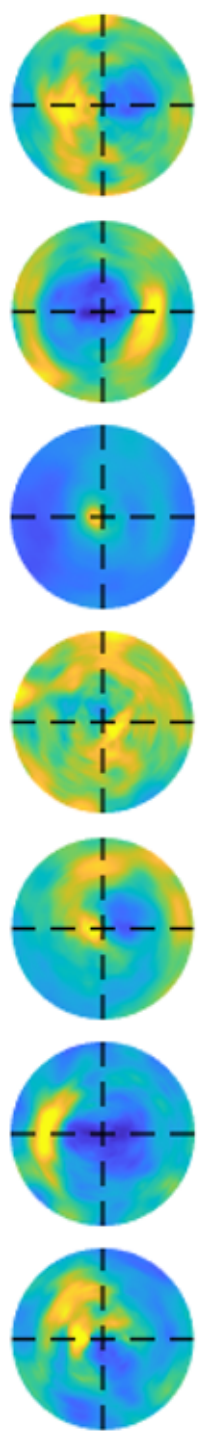
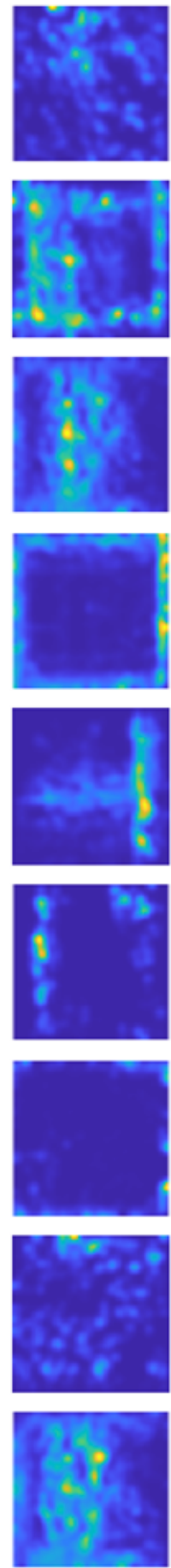
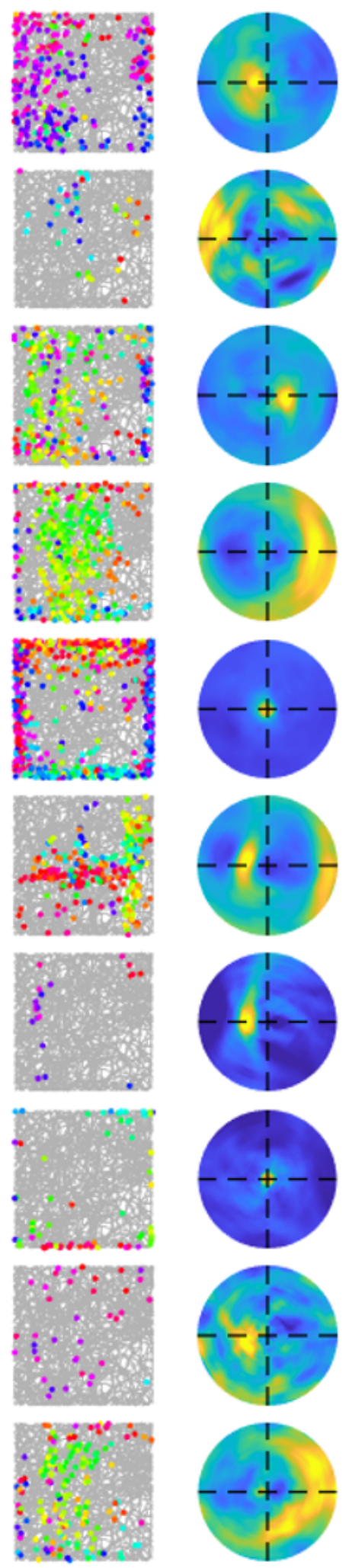
bioRxiv preprint doi: https://doi.org/10.1101/2022.01.28.478267; this version posted January 29, 2022. The copyright holder for this preprint (which was not certified by peer review) is the author/funder, who has granted bioRxiv a license to display the preprint in perpetuity. It is made available under aCC-BY-NC 4.0 International license.
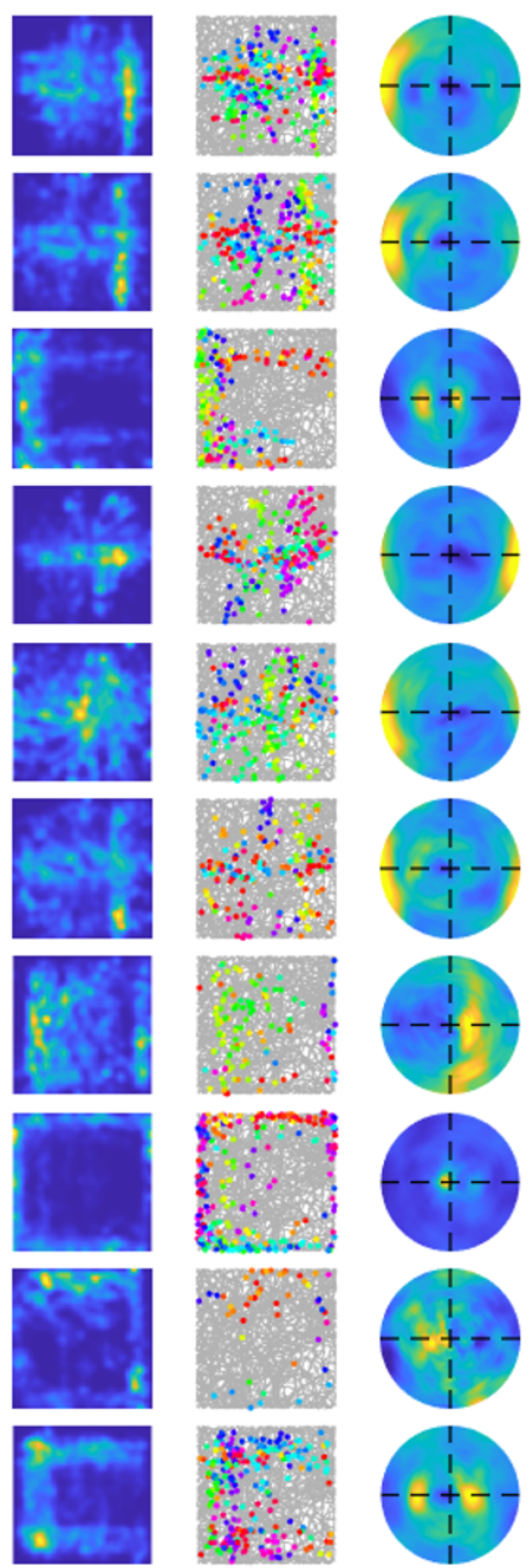
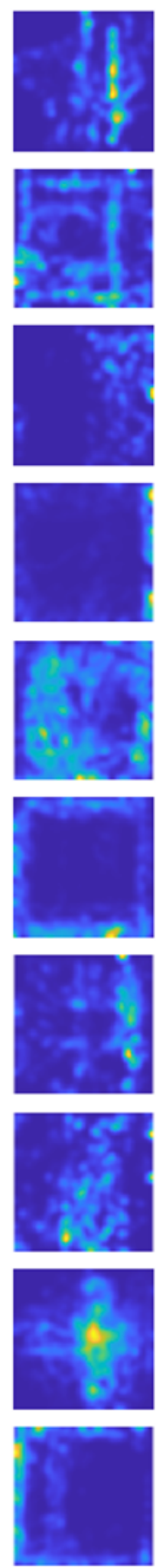
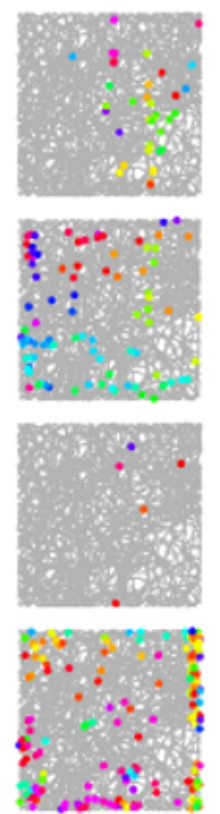
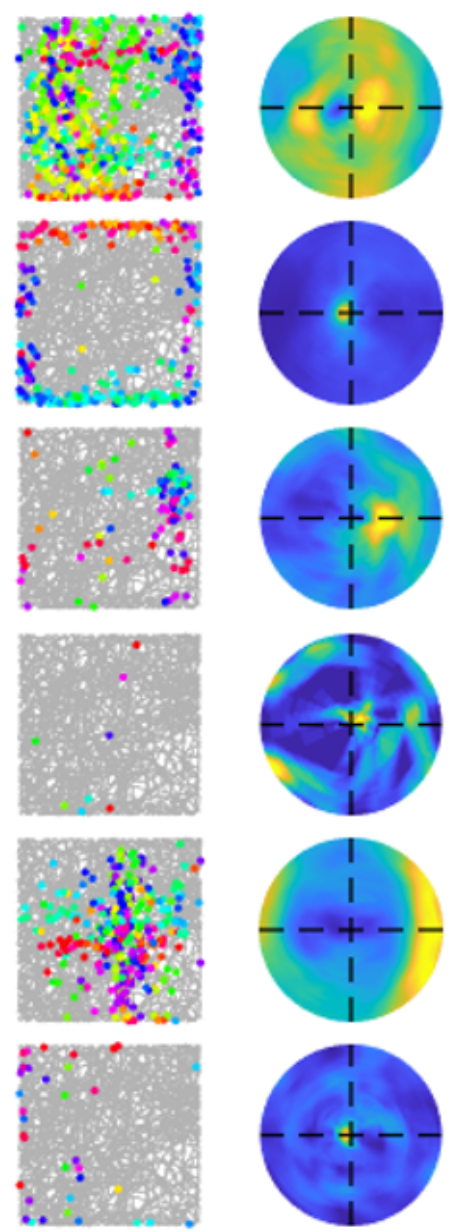
bioRxiv preprint doi: https://doi.org/10.1101/2022.01.28.478267; this version posted January 29, 2022. The copyright holder for this preprint (which was not certified by peer review) is the author/funder, who has granted bioRxiv a license to display the preprint in perpetuity. It is made available under aCC-BY-NC 4.0 International license.
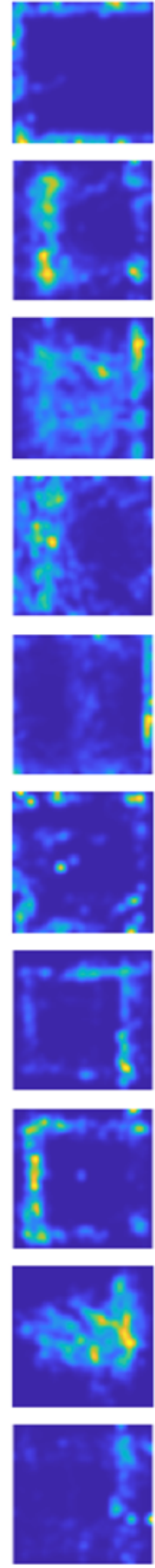
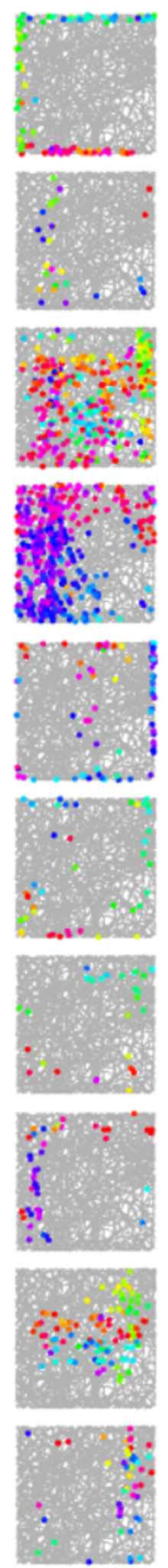
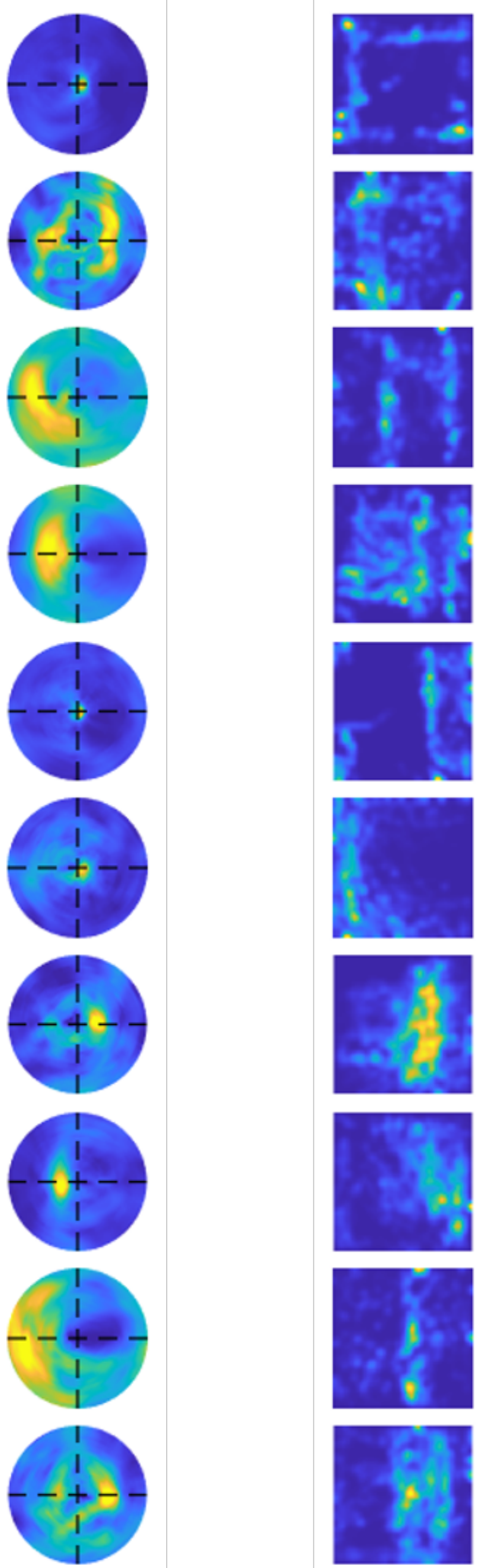
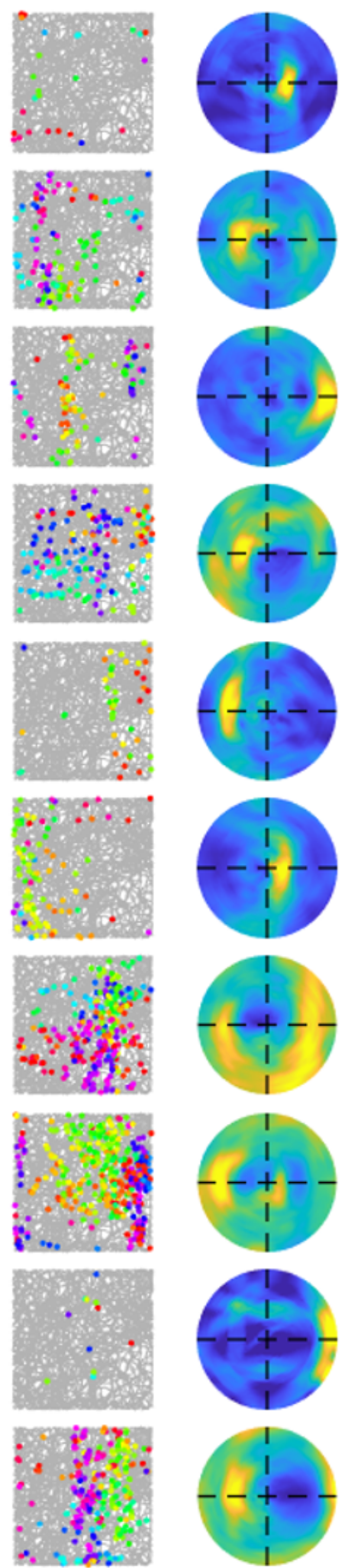
bioRxiv preprint doi: https://doi.org/10.1101/2022.01.28.478267; this version posted January 29, 2022. The copyright holder for this preprint (which was not certified by peer review) is the author/funder, who has granted bioRxiv a license to display the preprint in perpetuity. It is made available under aCC-BY-NC 4.0 International license.
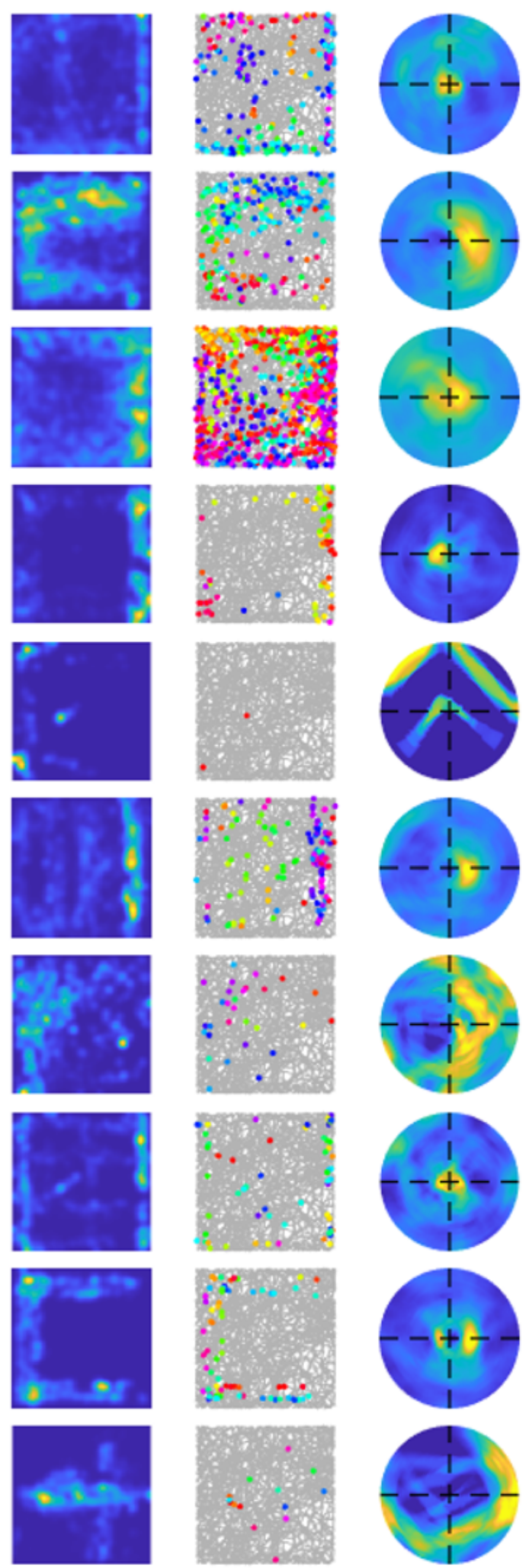
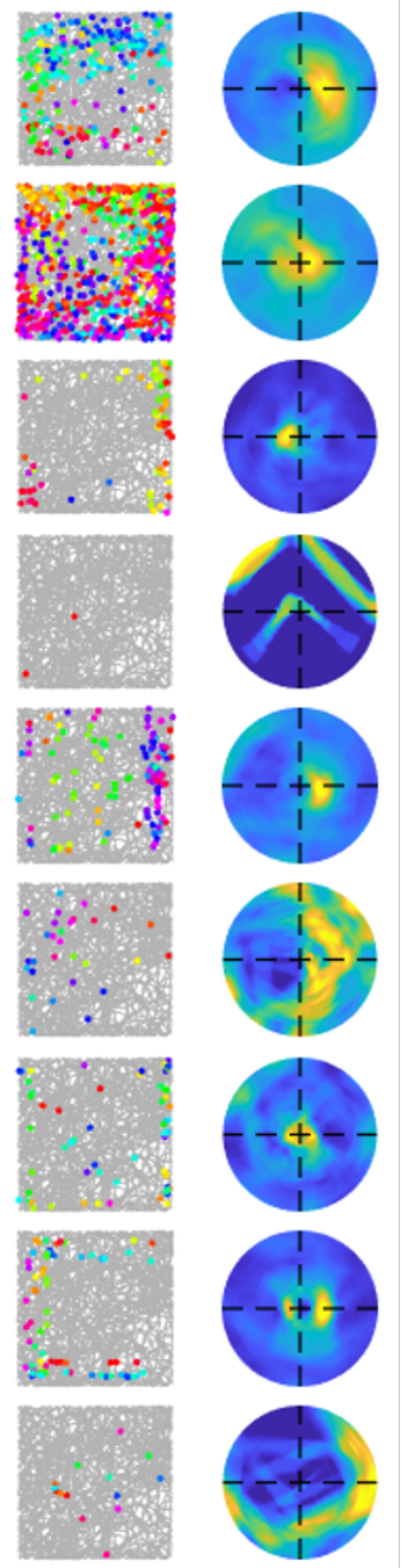
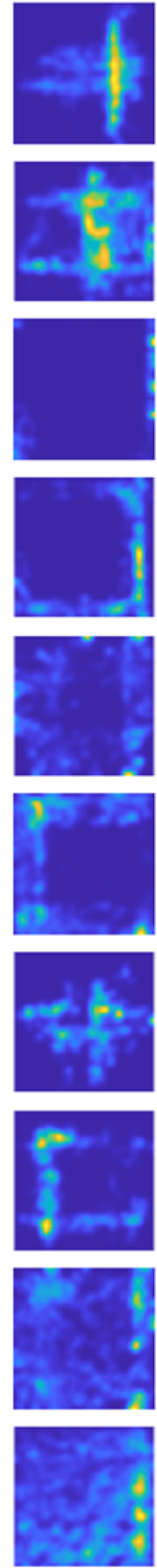
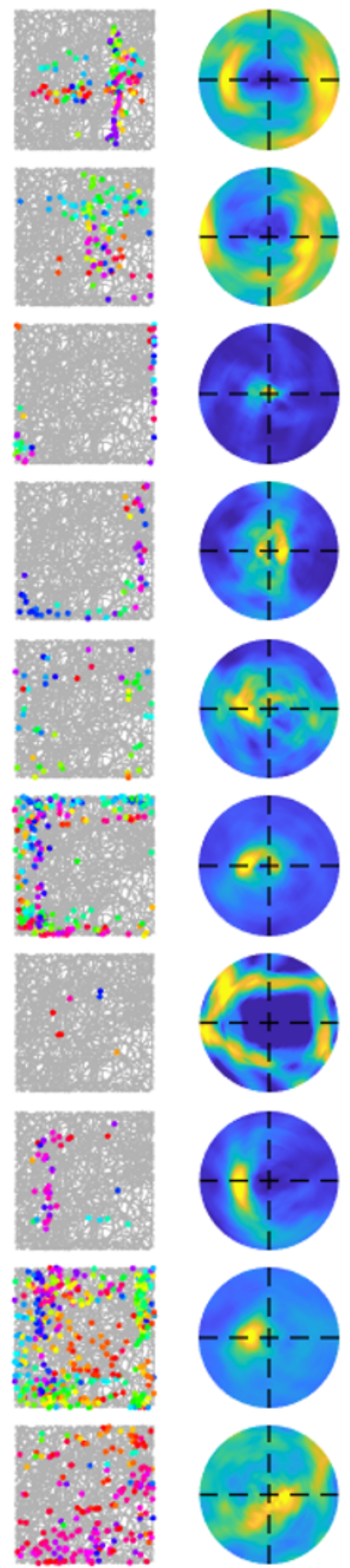
bioRxiv preprint doi: https://doi.org/10.1101/2022.01.28.478267; this version posted January 29, 2022. The copyright holder for this preprint (which was not certified by peer review) is the author/funder, who has granted bioRxiv a license to display the preprint in perpetuity. It is made available under aCC-BY-NC 4.0 International license.

\section{A.3 All learnt cells of Model II using experimental trajectory}
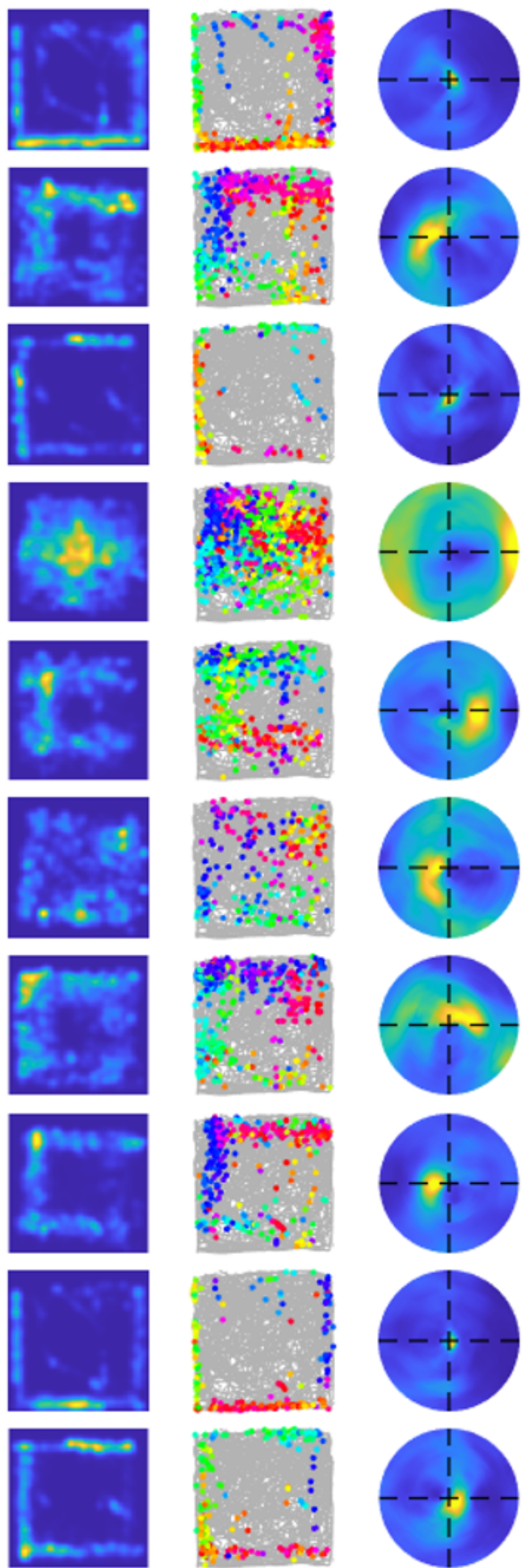
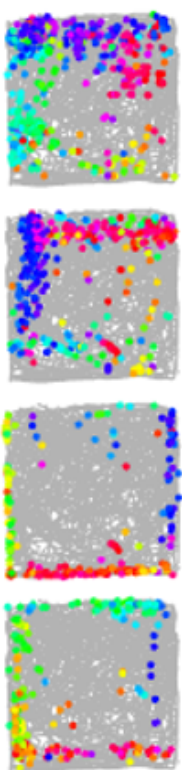
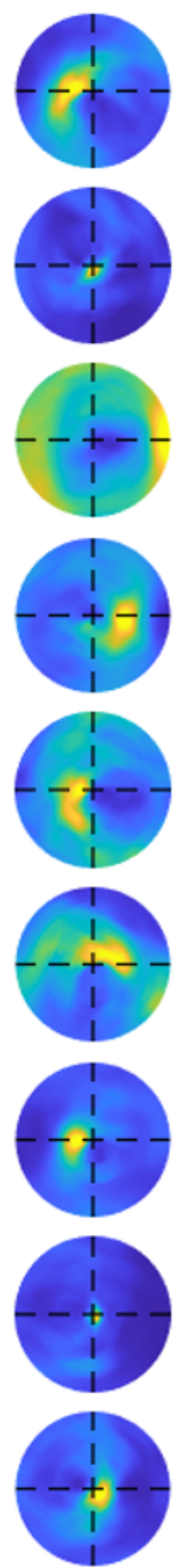
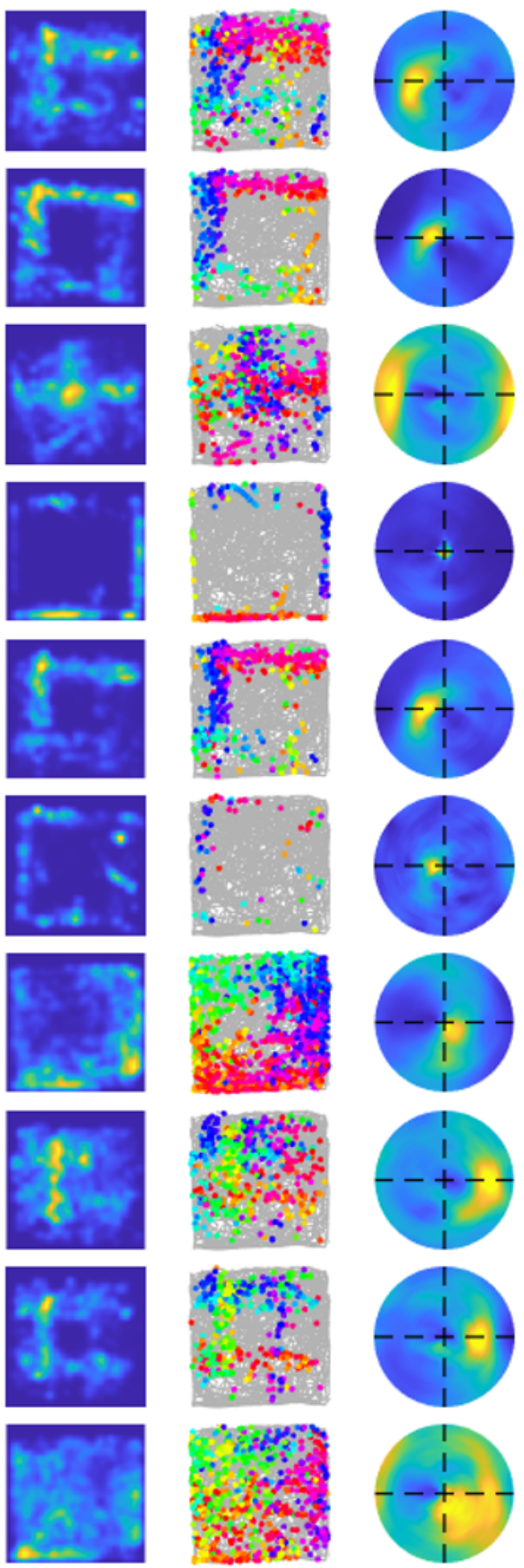
bioRxiv preprint doi: https://doi.org/10.1101/2022.01.28.478267; this version posted January 29, 2022. The copyright holder for this preprint (which was not certified by peer review) is the author/funder, who has granted bioRxiv a license to display the preprint in perpetuity. It is made available under aCC-BY-NC 4.0 International license.
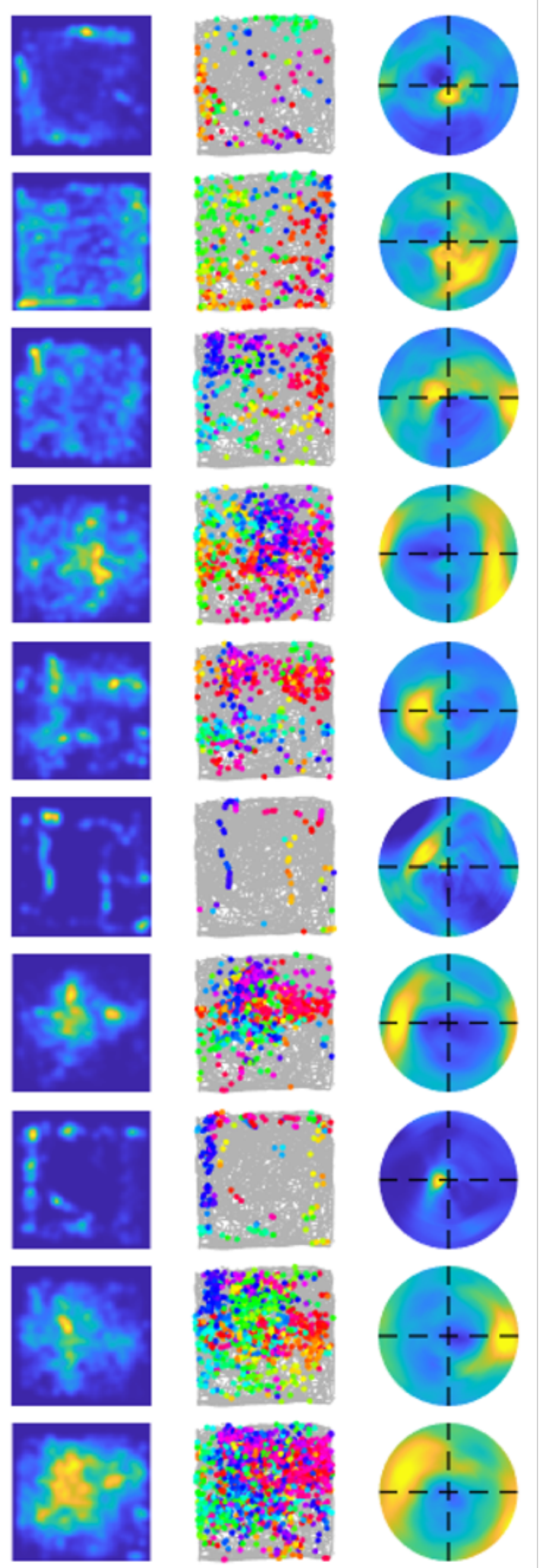
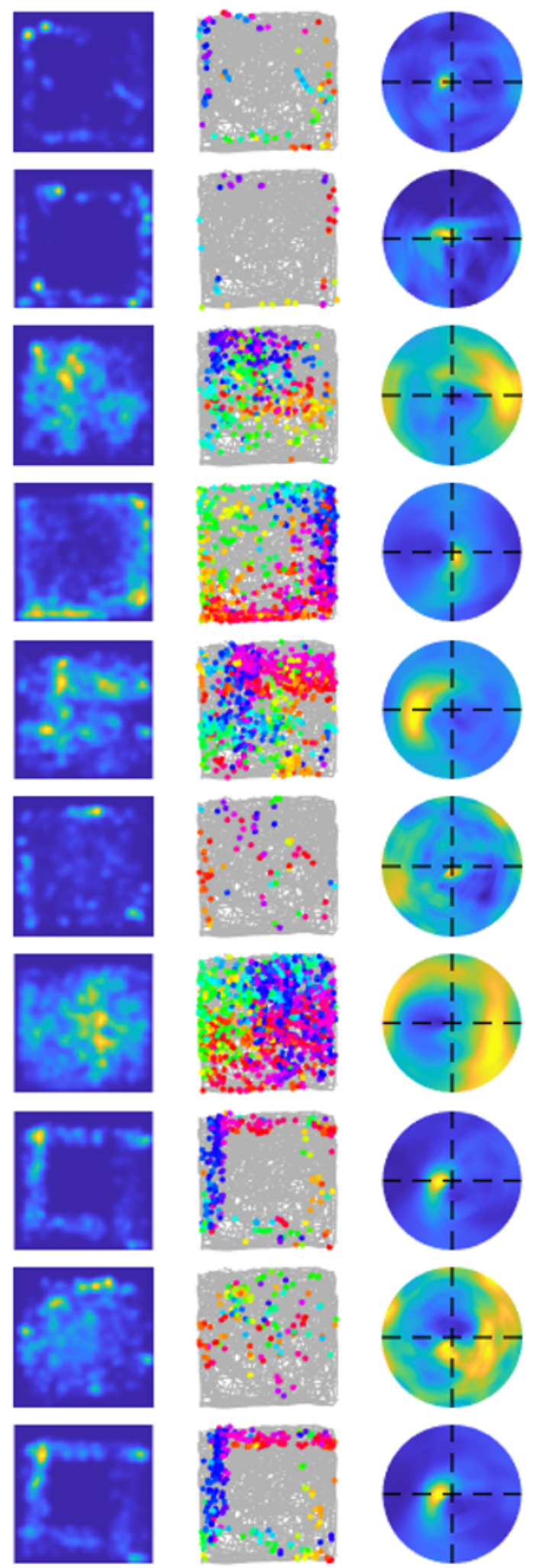
bioRxiv preprint doi: https://doi.org/10.1101/2022.01.28.478267; this version posted January 29, 2022. The copyright holder for this preprint (which was not certified by peer review) is the author/funder, who has granted bioRxiv a license to display the preprint in perpetuity. It is made available under aCC-BY-NC 4.0 International license.
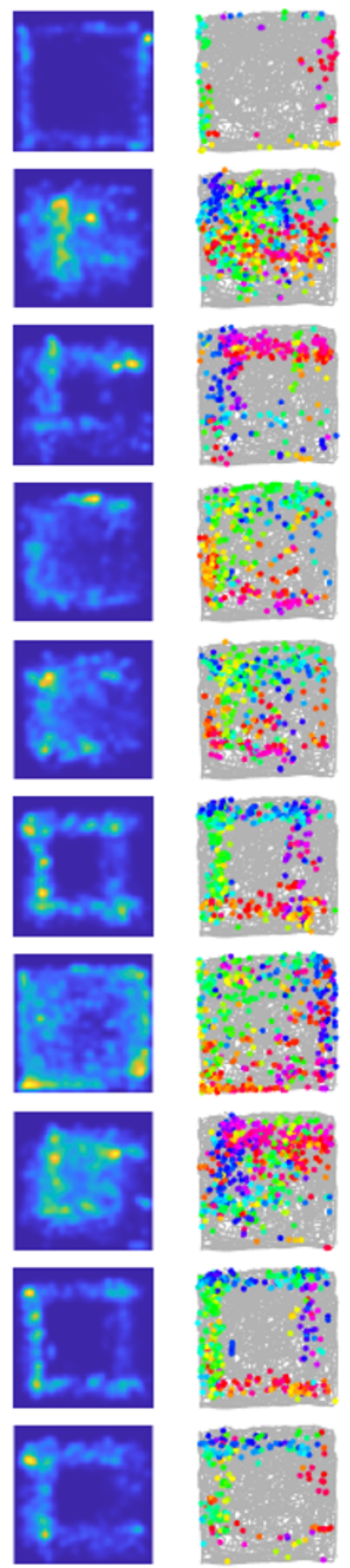
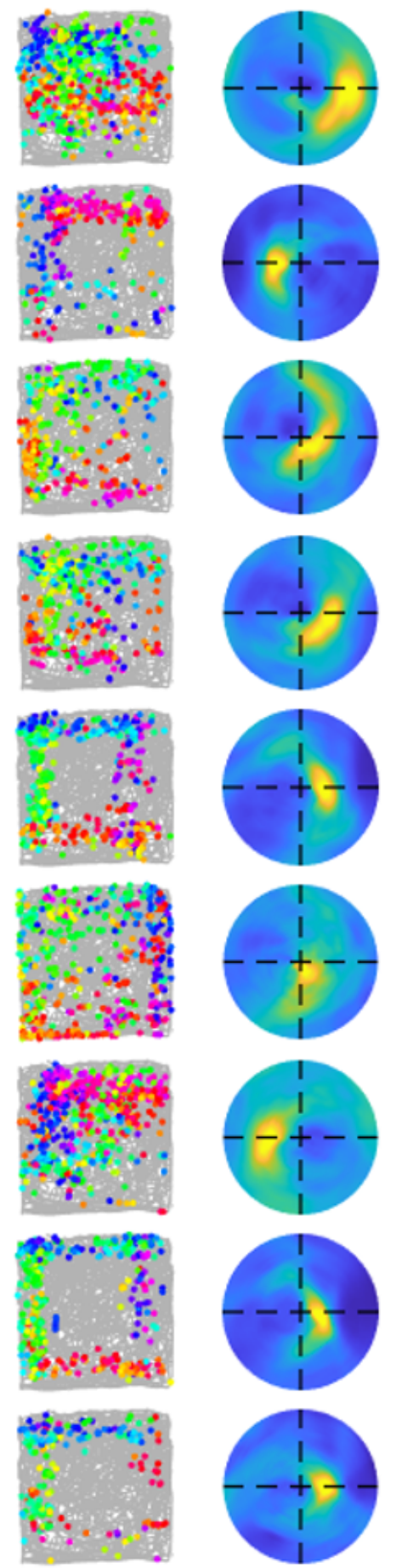
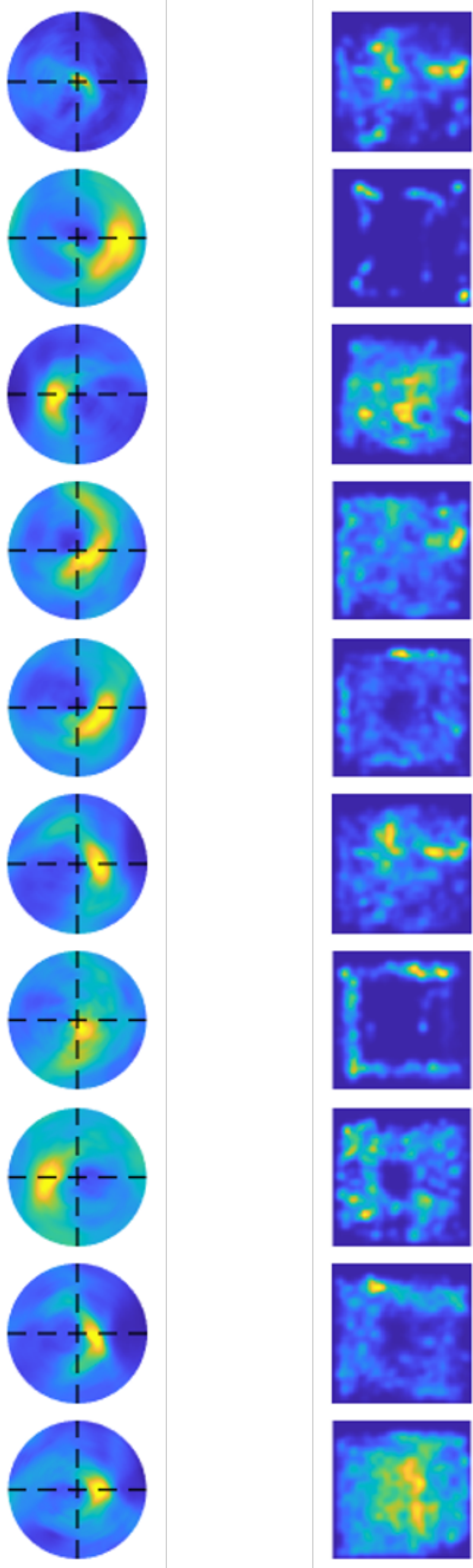
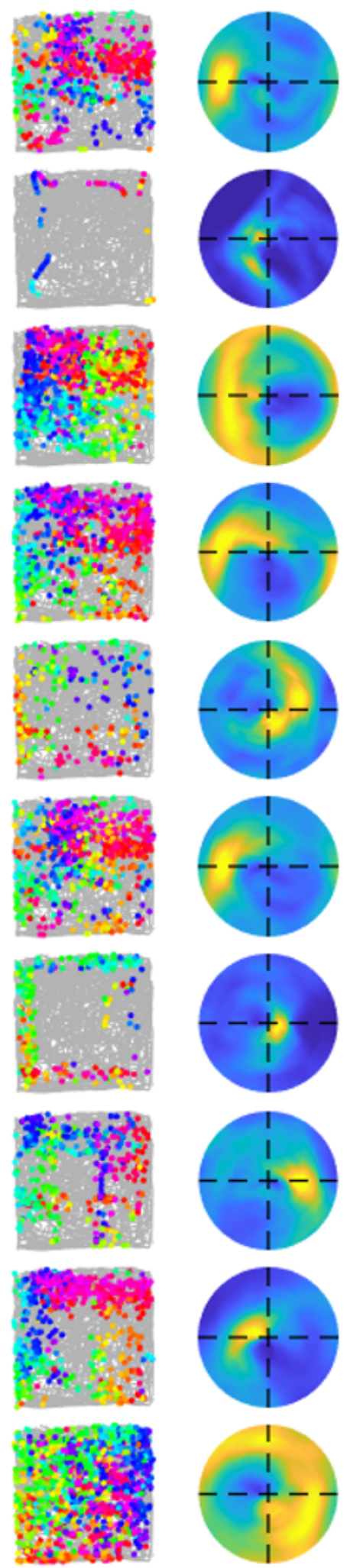
bioRxiv preprint doi: https://doi.org/10.1101/2022.01.28.478267; this version posted January 29, 2022. The copyright holder for this preprint (which was not certified by peer review) is the author/funder, who has granted bioRxiv a license to display the preprint in perpetuity. It is made available under aCC-BY-NC 4.0 International license.
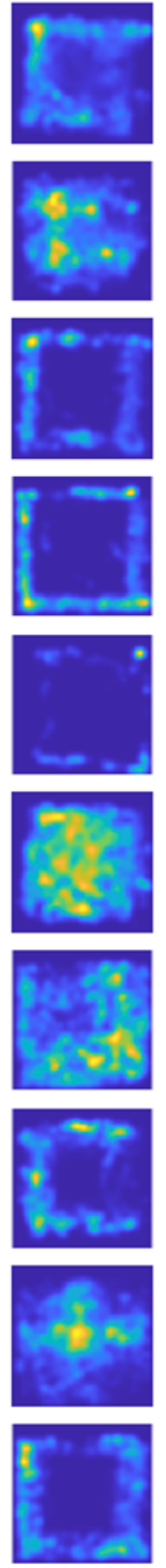
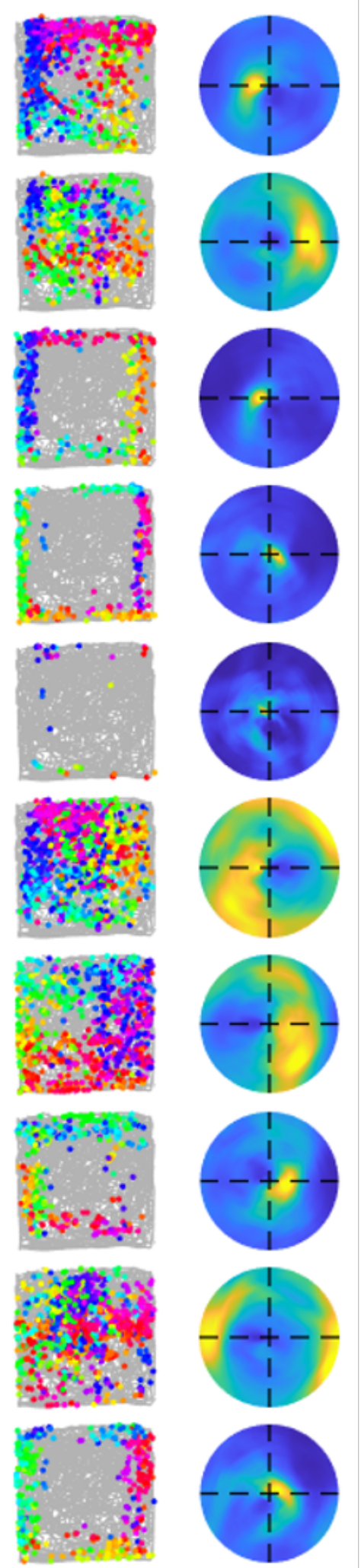
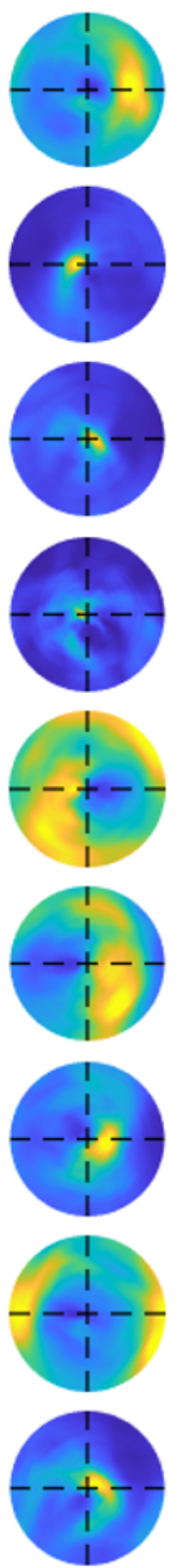

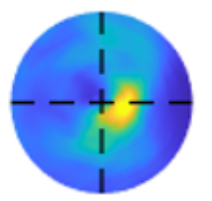

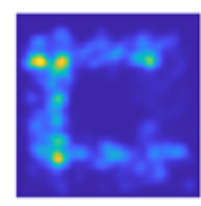
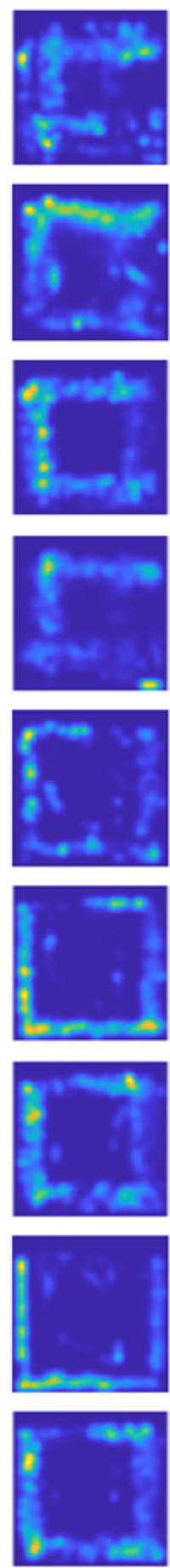
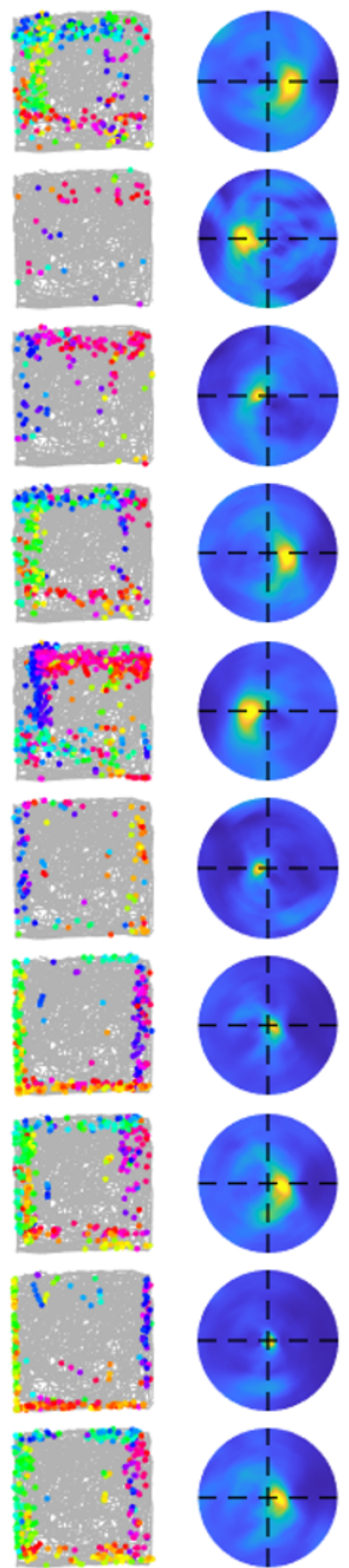
bioRxiv preprint doi: https://doi.org/10.1101/2022.01.28.478267; this version posted January 29, 2022. The copyright holder for this preprint (which was not certified by peer review) is the author/funder, who has granted bioRxiv a license to display the preprint in perpetuity. It is made available under aCC-BY-NC 4.0 International license.
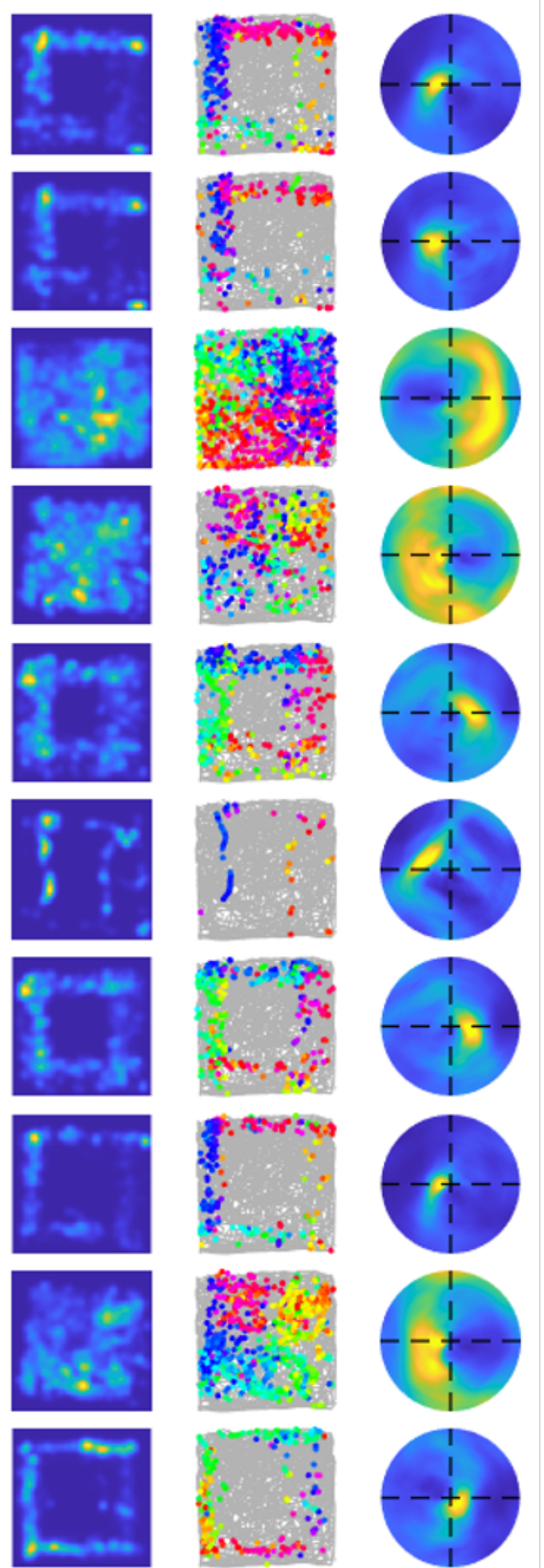
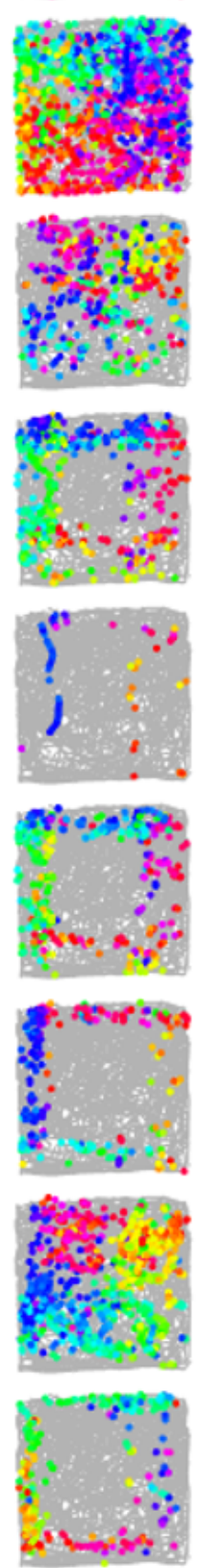
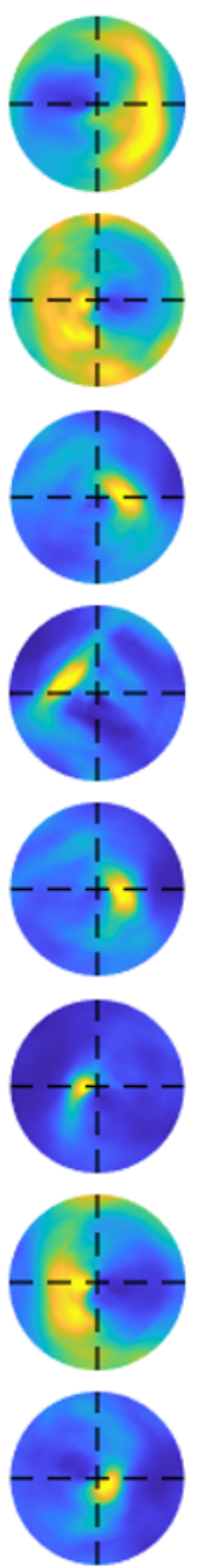
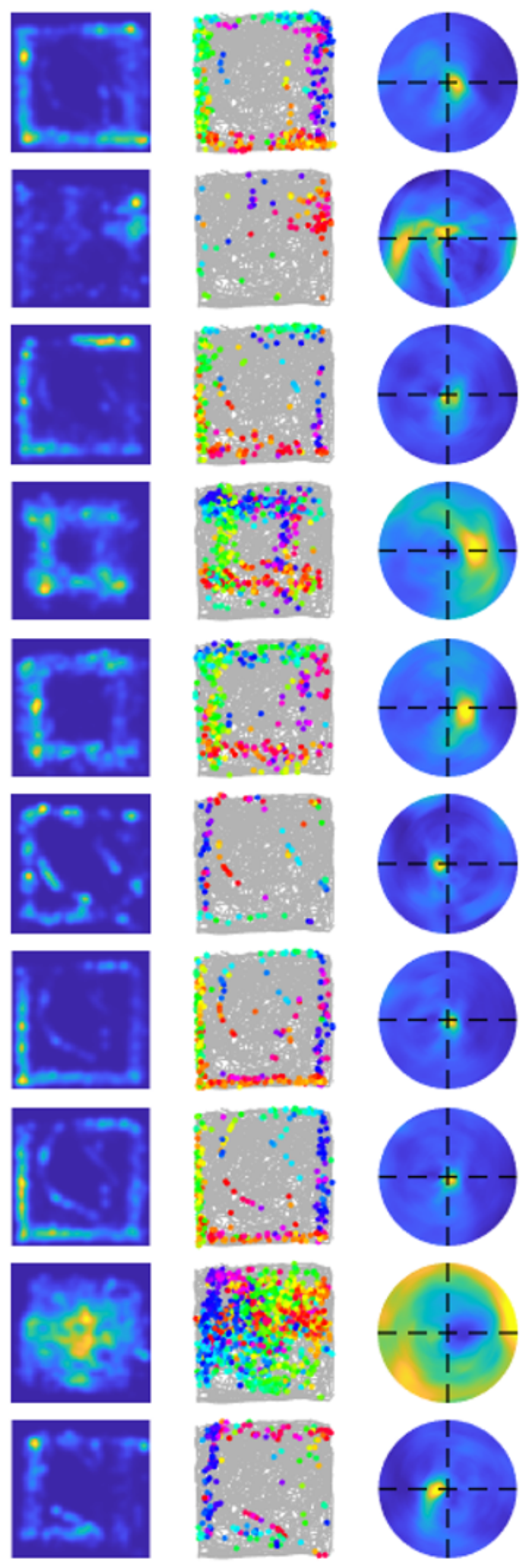
bioRxiv preprint doi: https://doi.org/10.1101/2022.01.28.478267; this version posted January 29, 2022. The copyright holder for this preprint (which was not certified by peer review) is the author/funder, who has granted bioRxiv a license to display the preprint in perpetuity. It is made available under aCC-BY-NC 4.0 International license.

\section{A.4 All learnt cells of Model II using simulated trajectory}
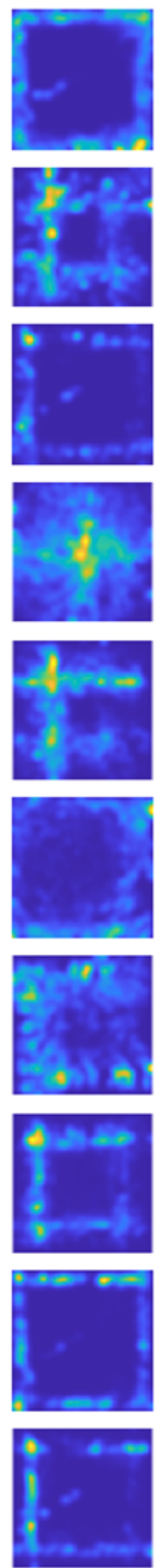
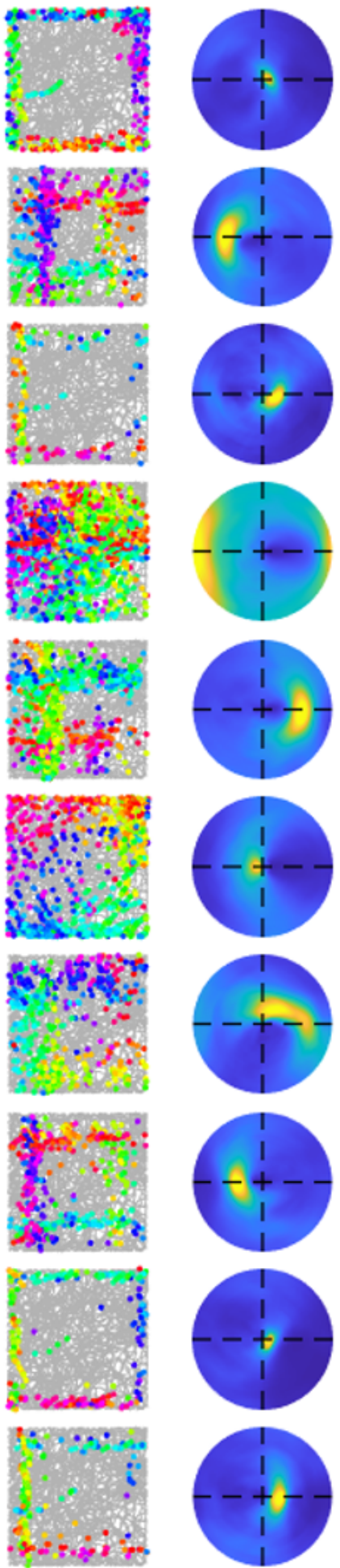
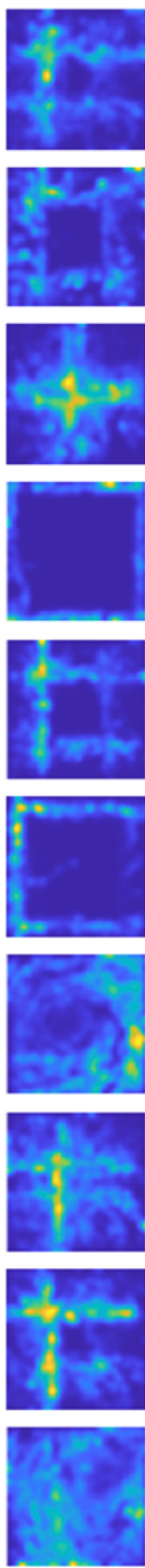
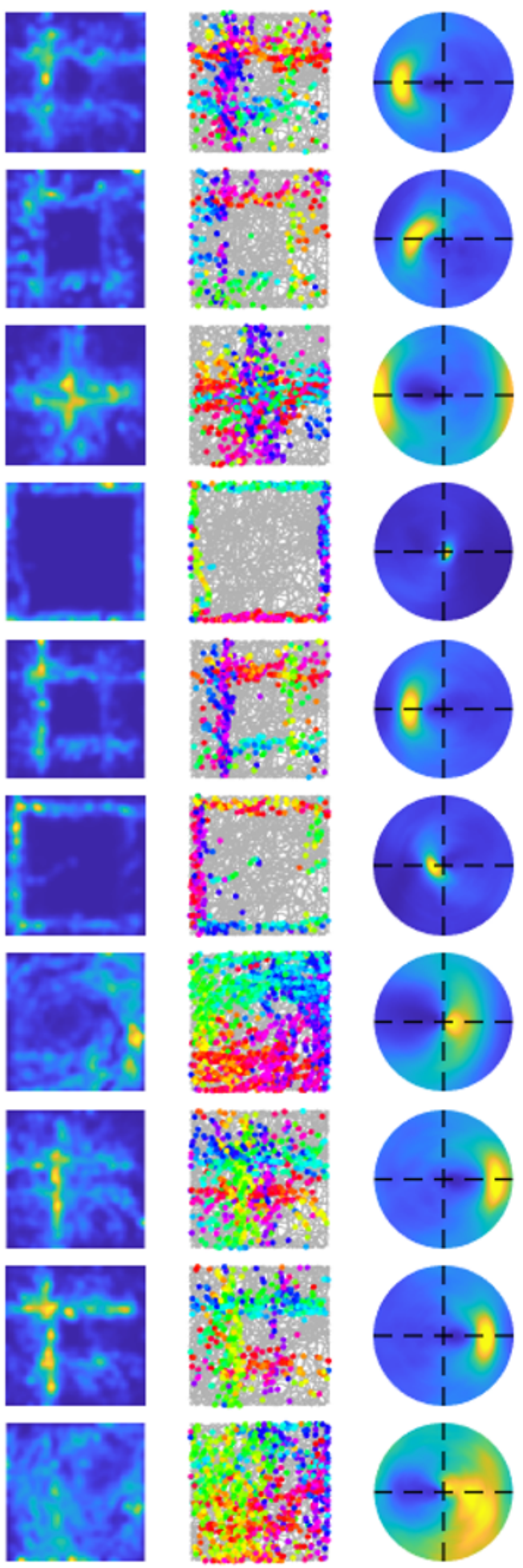
bioRxiv preprint doi: https://doi.org/10.1101/2022.01.28.478267; this version posted January 29, 2022. The copyright holder for this preprint (which was not certified by peer review) is the author/funder, who has granted bioRxiv a license to display the preprint in perpetuity. It is made available under aCC-BY-NC 4.0 International license.
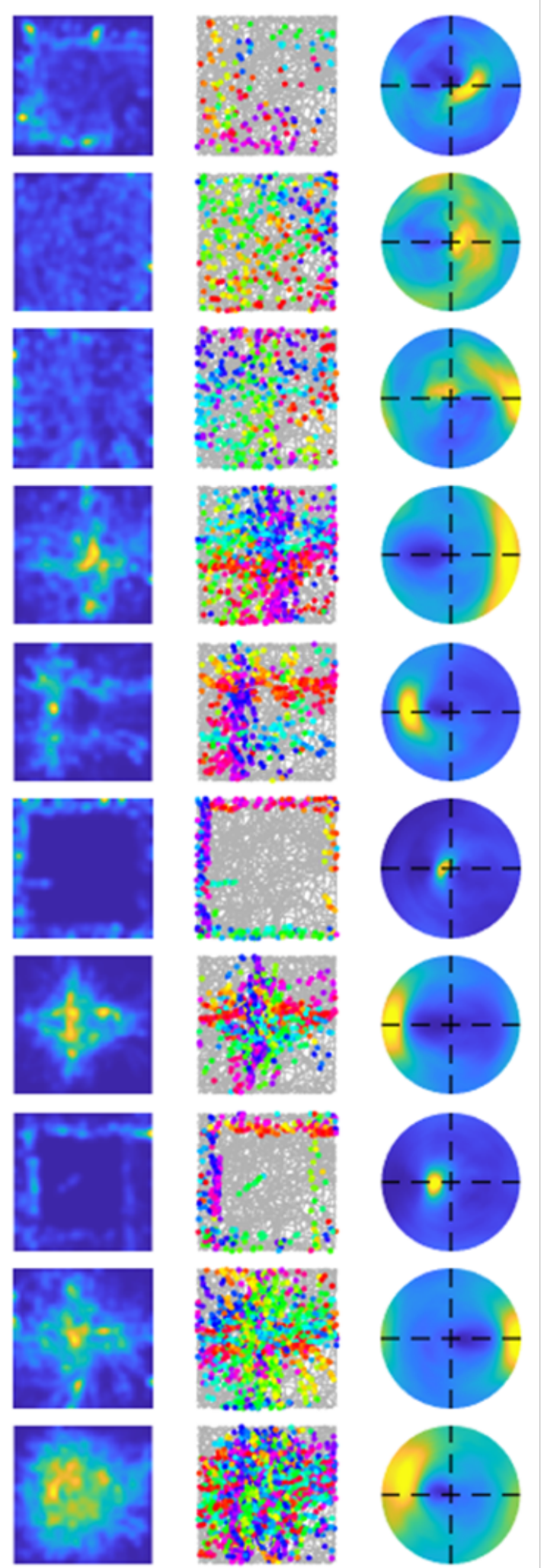
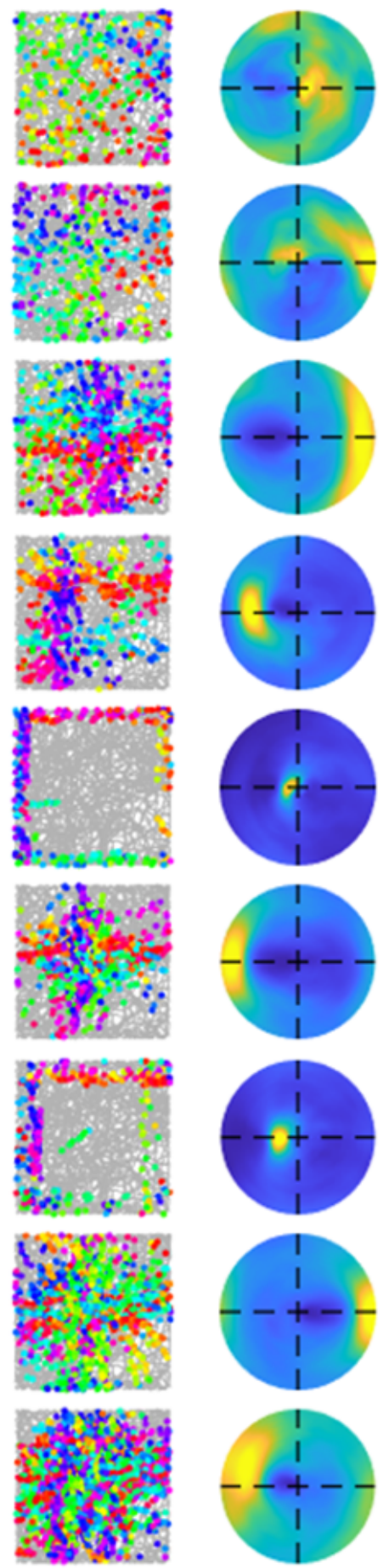

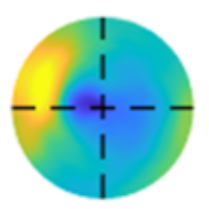

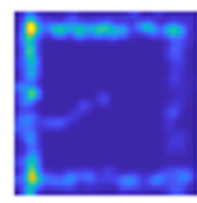
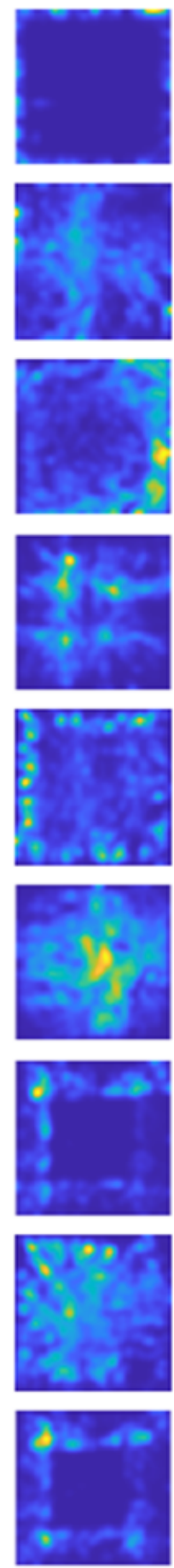
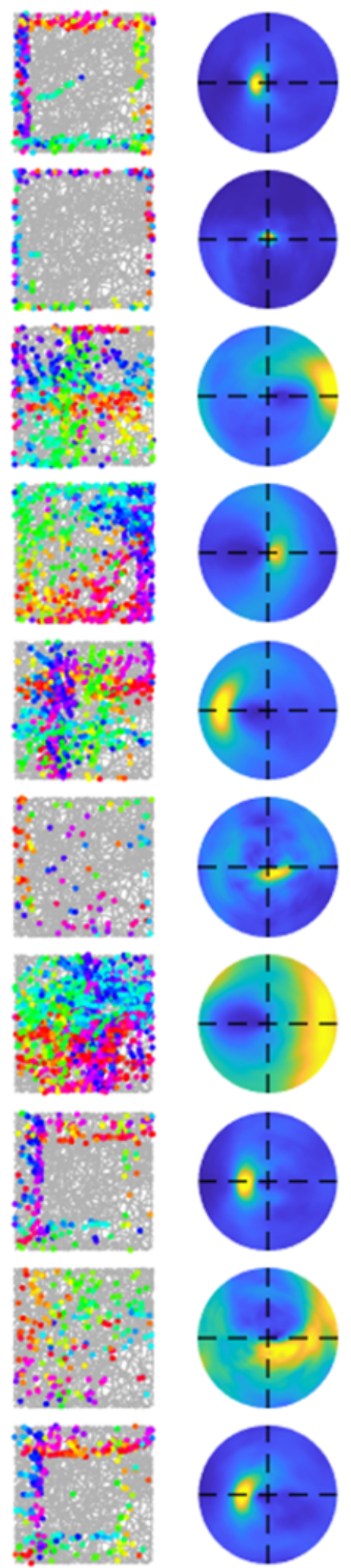
bioRxiv preprint doi: https://doi.org/10.1101/2022.01.28.478267; this version posted January 29, 2022. The copyright holder for this preprint (which was not certified by peer review) is the author/funder, who has granted bioRxiv a license to display the preprint in perpetuity. It is made available under aCC-BY-NC 4.0 International license.
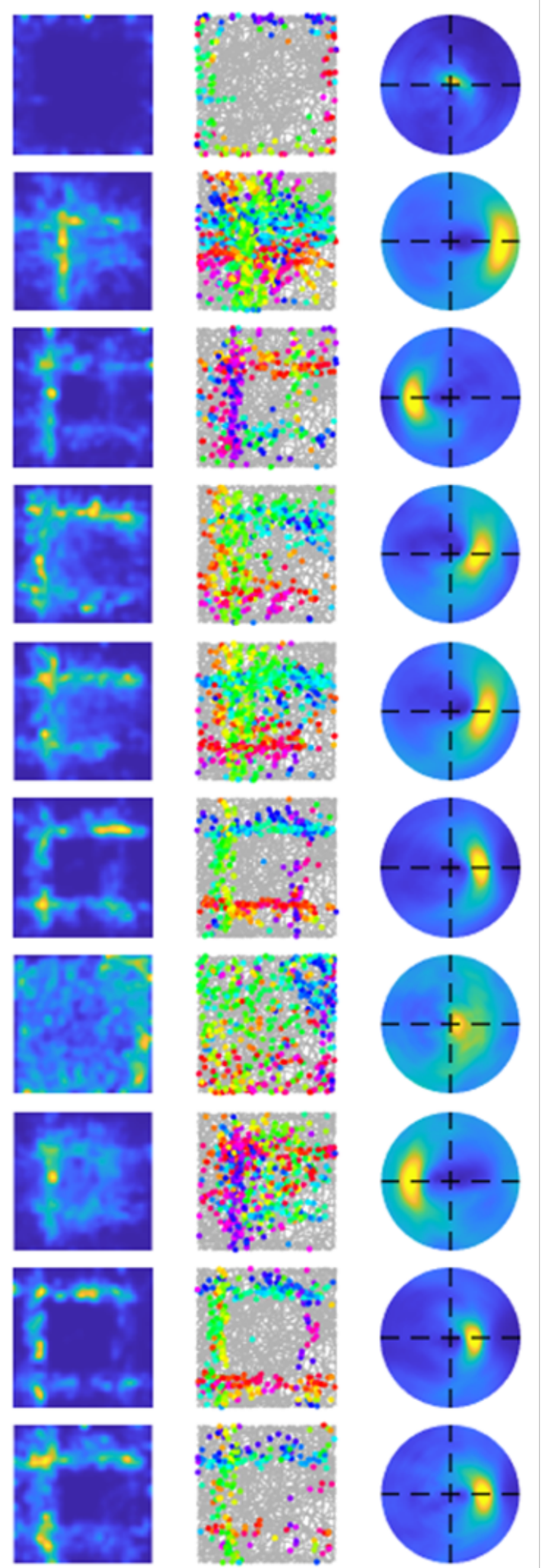
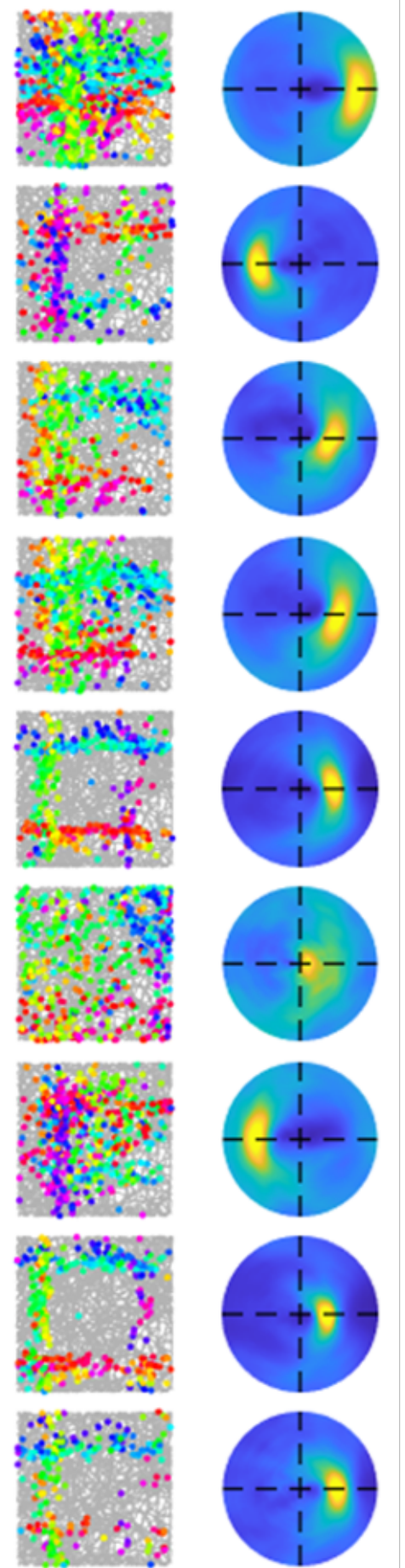
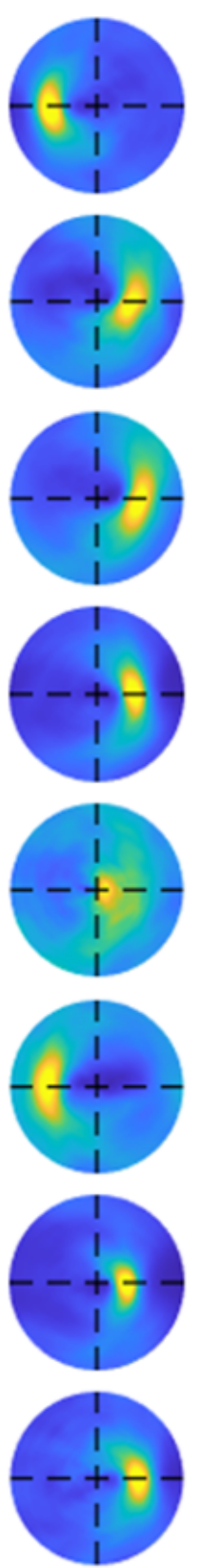
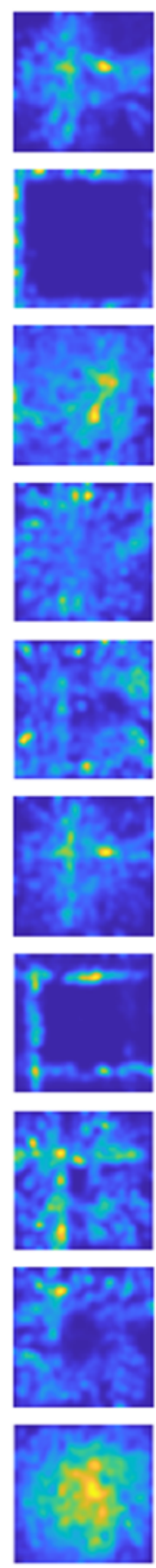
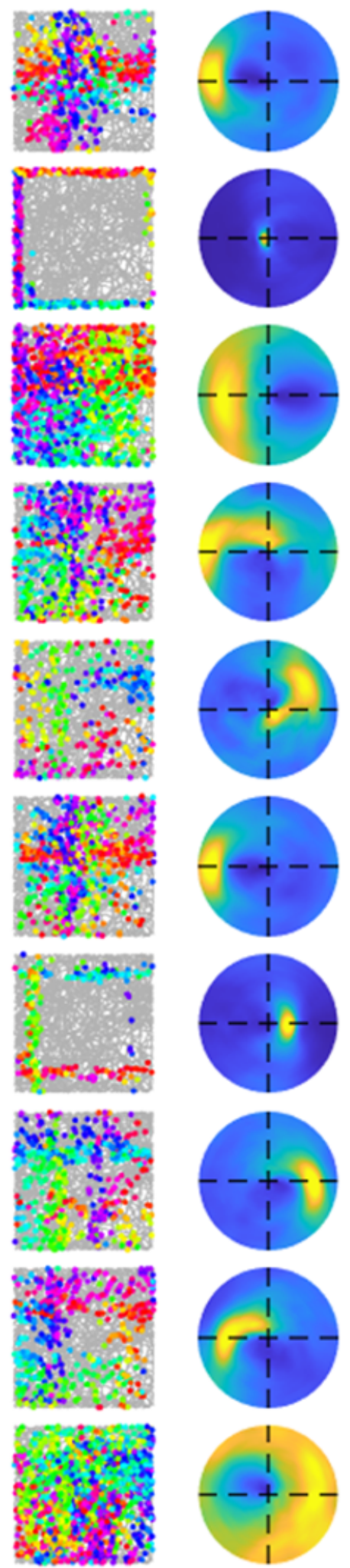
bioRxiv preprint doi: https://doi.org/10.1101/2022.01.28.478267; this version posted January 29, 2022. The copyright holder for this preprint (which was not certified by peer review) is the author/funder, who has granted bioRxiv a license to display the preprint in perpetuity. It is made available under aCC-BY-NC 4.0 International license.
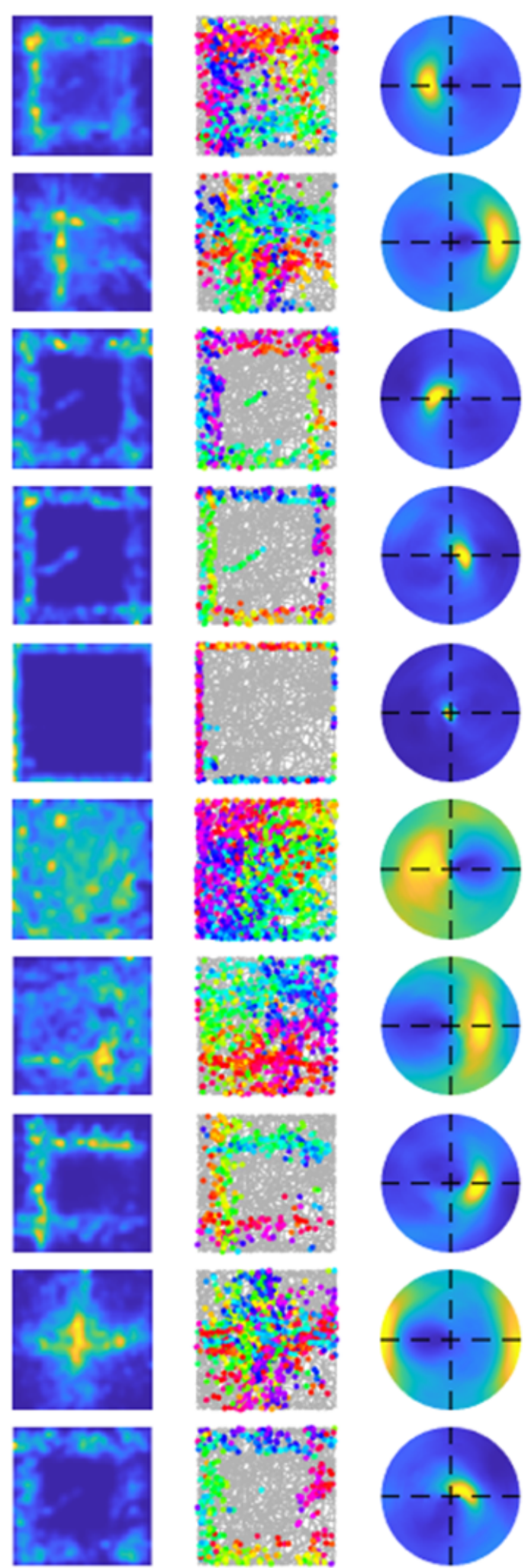
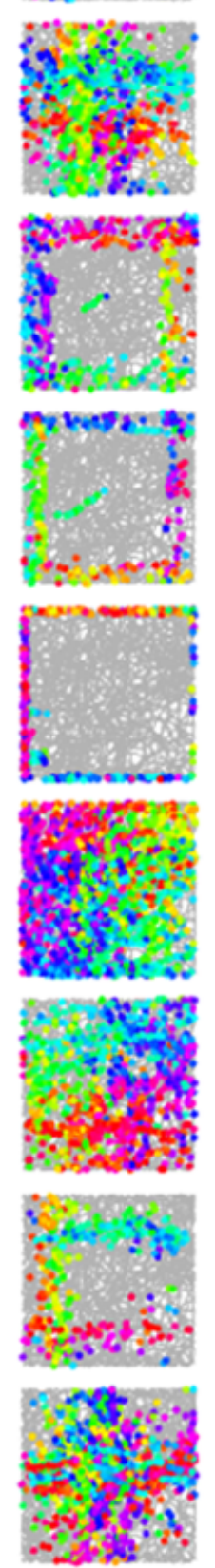

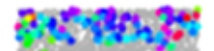

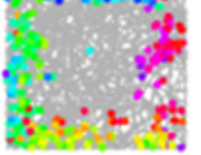

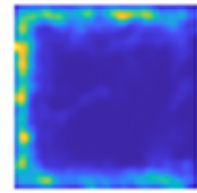
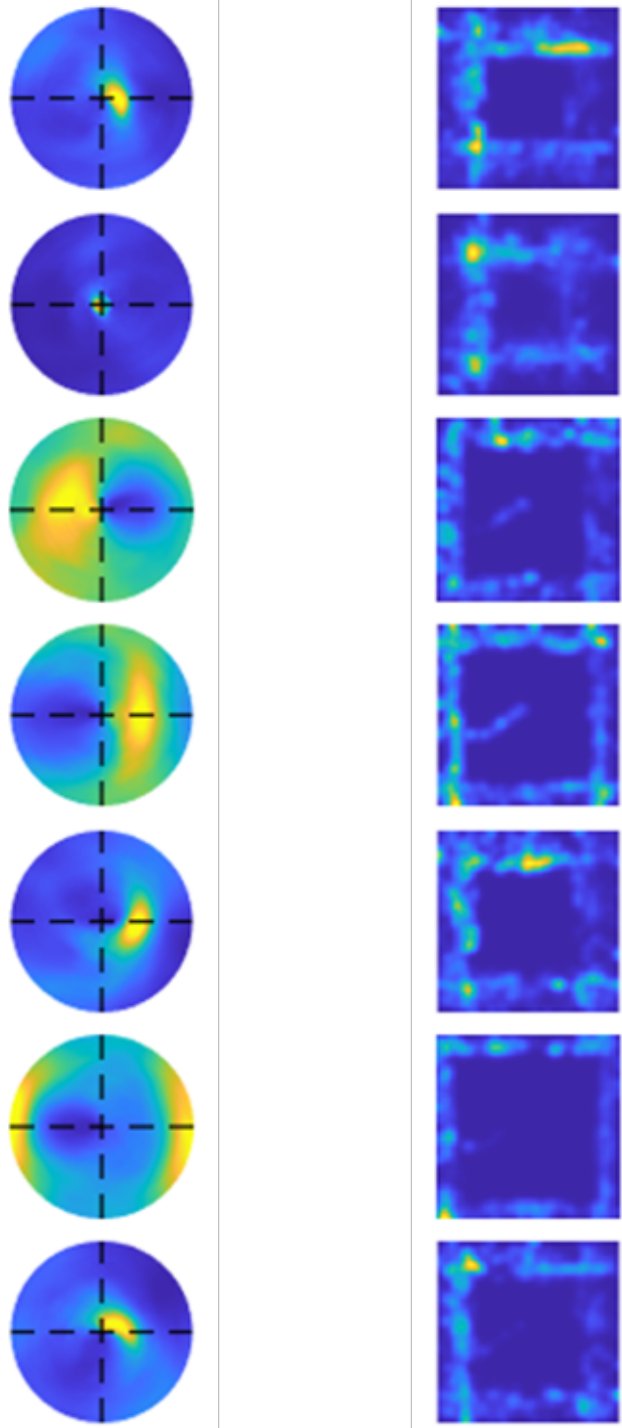
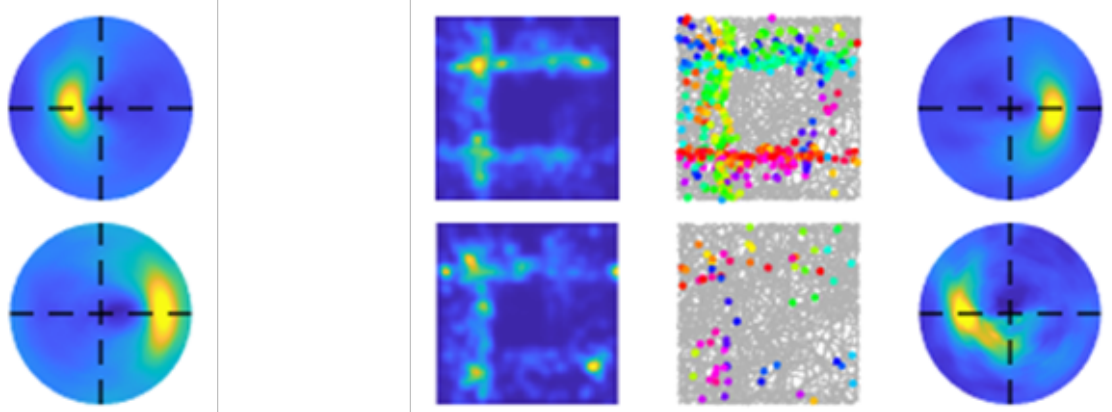
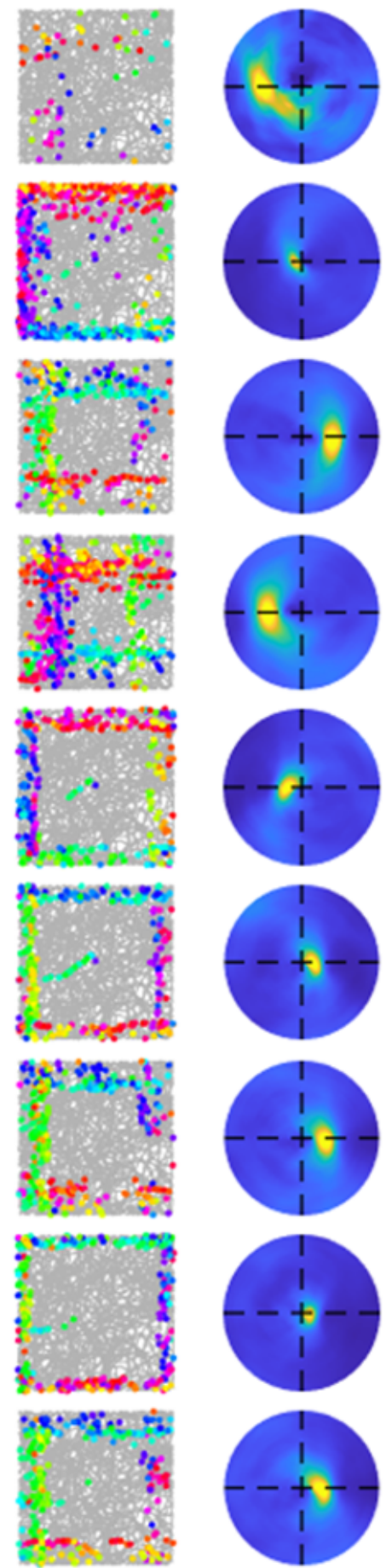
bioRxiv preprint doi: https://doi.org/10.1101/2022.01.28.478267; this version posted January 29, 2022. The copyright holder for this preprint (which was not certified by peer review) is the author/funder, who has granted bioRxiv a license to display the preprint in perpetuity. It is made available under aCC-BY-NC 4.0 International license.
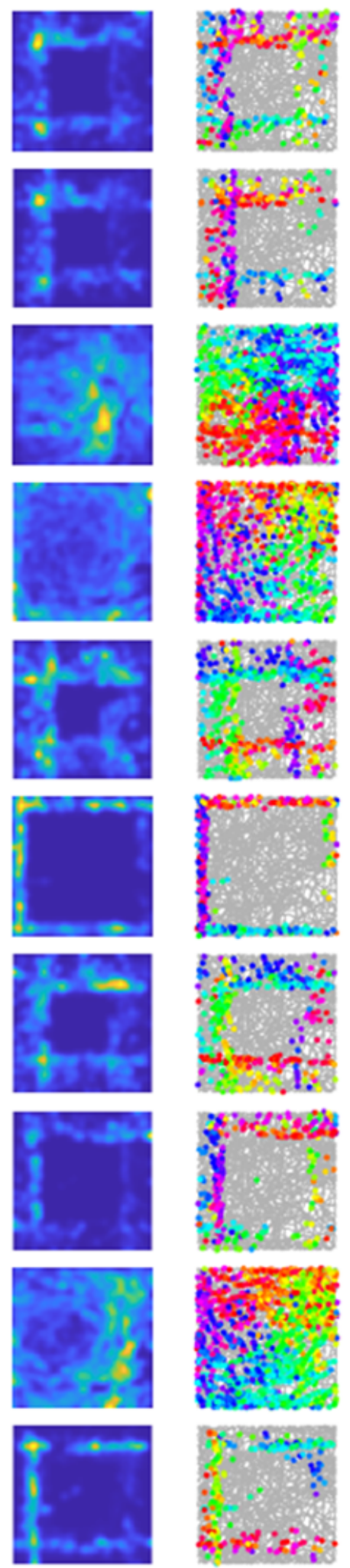

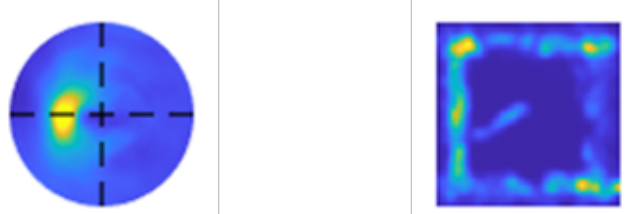

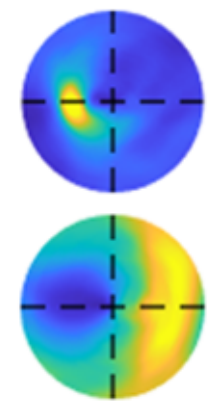
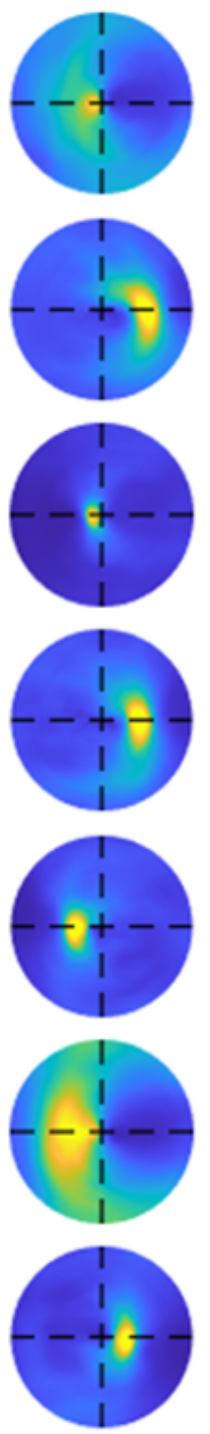
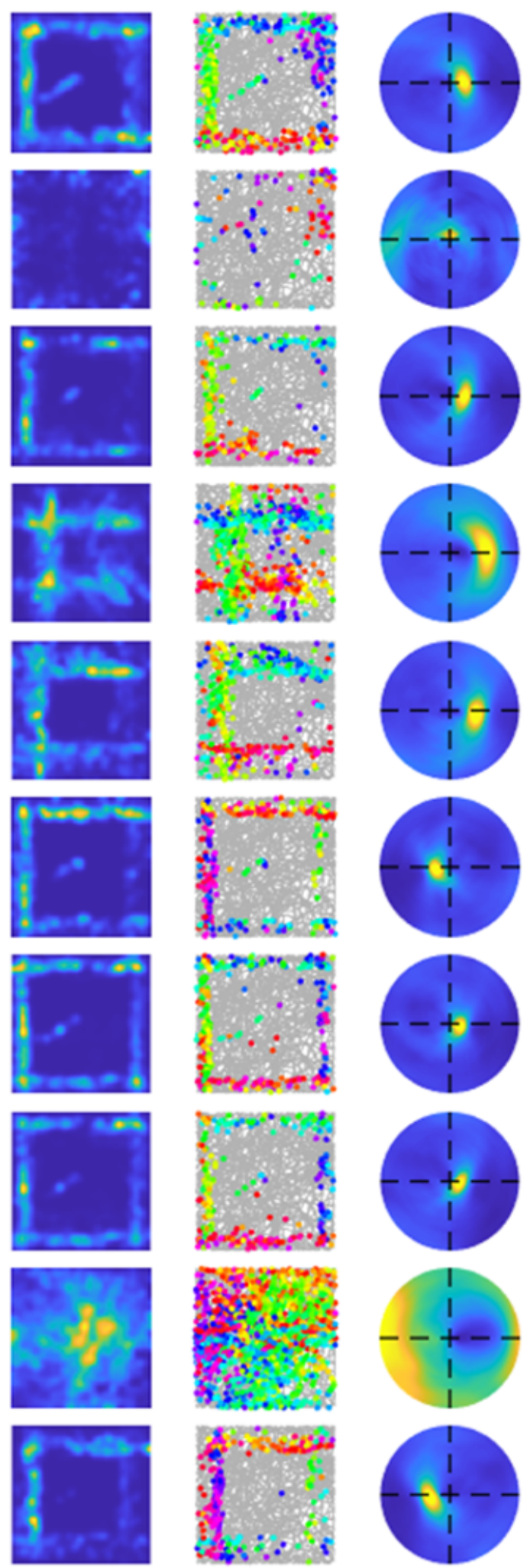